\title{
Utilizing conservation genetics as a strategy for recovering the endangered Candy Darter (Etheostoma osburni) in West Virginia
}

Brin E. Kessinger

West Virginia University, brin.kessinger@mail.wvu.edu

Follow this and additional works at: https://researchrepository.wvu.edu/etd

Part of the Biology Commons

\author{
Recommended Citation \\ Kessinger, Brin E., "Utilizing conservation genetics as a strategy for recovering the endangered Candy \\ Darter (Etheostoma osburni) in West Virginia" (2020). Graduate Theses, Dissertations, and Problem \\ Reports. 7670. \\ https://researchrepository.wvu.edu/etd/7670
}

This Thesis is protected by copyright and/or related rights. It has been brought to you by the The Research Repository @ WVU with permission from the rights-holder(s). You are free to use this Thesis in any way that is permitted by the copyright and related rights legislation that applies to your use. For other uses you must obtain permission from the rights-holder(s) directly, unless additional rights are indicated by a Creative Commons license in the record and/ or on the work itself. This Thesis has been accepted for inclusion in WVU Graduate Theses, Dissertations, and Problem Reports collection by an authorized administrator of The Research Repository @ WVU. For more information, please contact researchrepository@mail.wvu.edu. 
Utilizing conservation genetics as a strategy for recovering the endangered Candy Darter (Etheostoma osburni) in West Virginia

\title{
Brin Kessinger
}

\author{
Thesis submitted to the \\ Davis College of Agriculture, Natural Resources and Design \\ at West Virginia University \\ in partial fulfillment of the requirements for the degree of \\ Master of Science in \\ Wildlife and Fisheries Resources
}

Amy B. Welsh, Ph.D.

Stuart A. Welsh, Ph.D., Jacquelyn Strager, M.S.

Division of Forestry and Natural Resources

\section{Morgantown, \\ WV 2020}

Keywords: population genetics, conservation units, reintroduction, translocation, hybridization, invasive, Etheostoma, osburni, variatum, New River, Gauley, Greenbrier, Distinct Population Segment, DPS, Evolutionarily Significant Unit, ESU 


\section{ABSTRACT \\ Utilizing conservation genetics as a strategy for recovering the endangered Candy Darter (Etheostoma osburni) in West Virginia}

\section{Brin Kessinger}

The Candy Darter (Etheostoma osburni) is a small freshwater fish native to the New River drainage in West Virginia and Virginia that was listed as endangered in November 2018. It has been extirpated from much of its historic range in West Virginia, restricting it to the Gauley and Greenbrier river drainages. In addition to extirpations, the species is threatened by introgressive hybridization with the invasive Variegate Darter (E. variatum). Previous research primarily focused on hybridization, but population genetic analyses were limited. Population genetic analyses aim to identify distinct populations through genetic structure and characterize the levels of genetic diversity amongst those populations. A series of reintroductions of wildcaught individuals from the Greenbrier River drainage was performed to create new populations that were not under threat of hybridization. Fish were stocked into Camp Creek and the Little Bluestone River in the Bluestone River drainage of southern West Virginia. Individuals from throughout the Greenbrier and Gauley River drainages along with the newly introduced individuals were genotyped with 12 microsatellite loci to assess their population structure and diversity. These results were used to make recommendations about conservation units and future reintroduction efforts. A watershed-level landscape assessment was performed on the Camp Creek and Little Bluestone River watersheds to compare the source habitat to the new habitat. There is strong evidence that the Greenbrier drainage population and the Gauley River drainage population are highly distinct and represent separate ESUs that should be treated as separate Recovery Units (RUs). The reintroduced population's genetic diversity captures the diversity of the source (Greenbrier drainage), but the landscapes of the new watersheds present some challenges to managers with higher levels of agriculture, resource extraction, and private land. The long-term persistence of E. osburni populations relies on continued monitoring and management of their genetics. 


\section{ACKNOWLEDGMENTS}

I would like to acknowledge my graduate committee, Dr. Amy Welsh, Dr. Stuart Welsh, and Jacquelyn Strager for their guidance, expertise, and flexibility. I would also like to thank Isaac Gibson for all of the field and lab work that helped make this study possible. His commitment to the recovery of the Candy Darter was unmatched. Thank you, Daniel Cincotta, Nathaniel Owens, David Okernick, Paul Robert, Dustin Kimble, and David Thorne and all of the other employees from the West Virginia Division of Natural Resources, for field collections. Thank you to all the other professionals, volunteers, and researchers who helped with field collections. Thank you to the West Virginia Cooperative Fish and Wildlife Research Unit faculty, staff, and students for their support. I want to acknowledge Caroline Harms, Lucas Price, Mary Ackers, Yvette Halley, and Rachel Honerlaw from the Wild Genomics lab for challenging me and helping me in the lab. Additionally, thank you to all the Division of Forestry and Natural Resources graduate students at WVU for your commiseration and making this experience so much fun. Finally, I want to thank my family. I would not be in this position without the continuous support and encouragement of my parents Earl and Nancy Kessinger. I could not have finished without the help of my husband Kevin Gibbons and his parents Dr. Joseph Gibbons and Dr. Kathryn Riedel.

I would like to acknowledge my funding sources, the U.S. Fish and Wildlife Service and the U.S. Geological Survey. I want to thank the WVU Genomics Core Facility, Morgantown WV for support provided to help make this thesis possible and CTSI Grant \#U54 GM104942 which in turn provides financial support to the Core Facility. This work was also supported by the USDA National Institute of Food and Agriculture, Hatch project WVA00690, and the West Virginia Agricultural and Forestry Experiment Station. 


\section{TABLE OF CONTENTS}

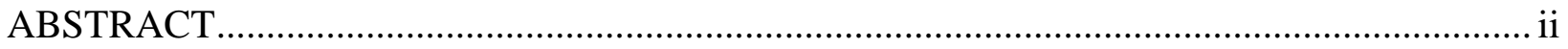

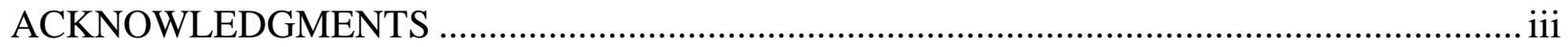

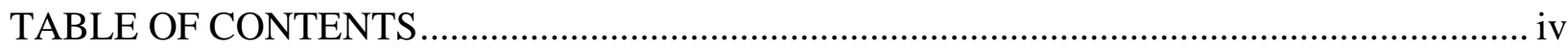

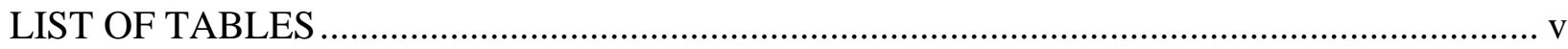

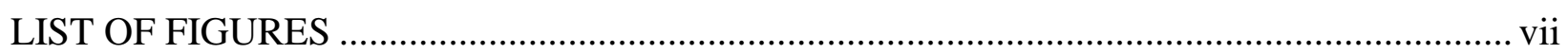

Chapter 1: Introduction and Literature Review …………....................................................... 1

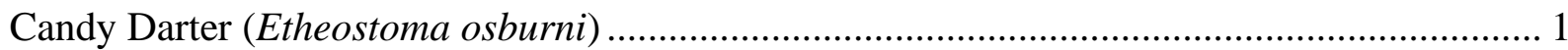

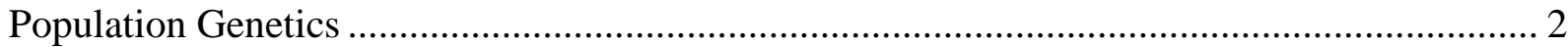

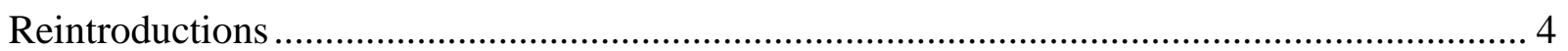

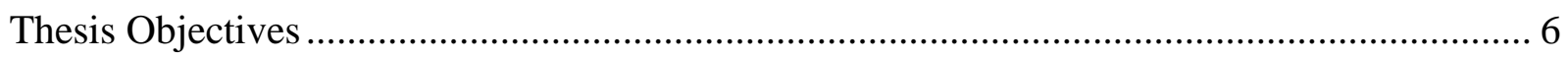

Chapter 2: Population genetics and conservation units of the Candy Darter (Etheostoma osburni)

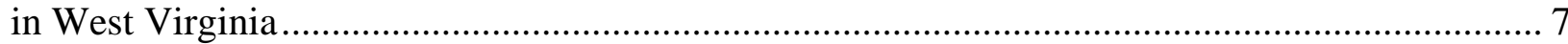

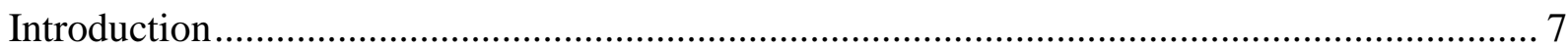

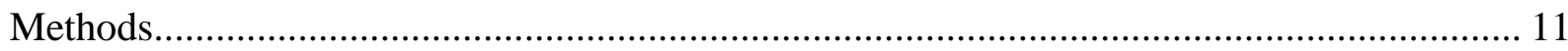

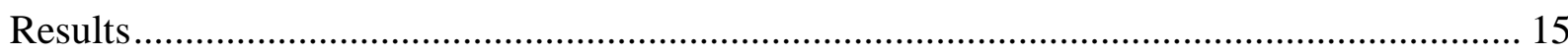

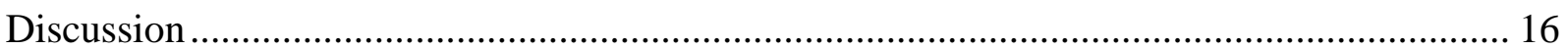

Chapter 3: Genetic evaluation of reintroduced Candy Darters to Camp Creek and the Little Bluestone River with a watershed level landscape analysis ........................................................ 22

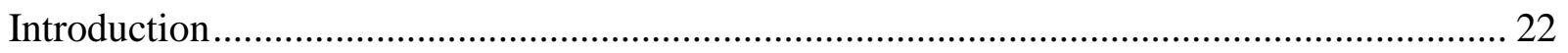

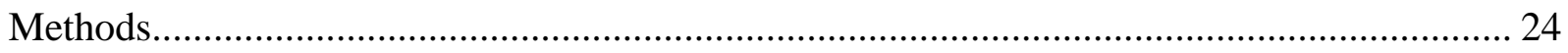

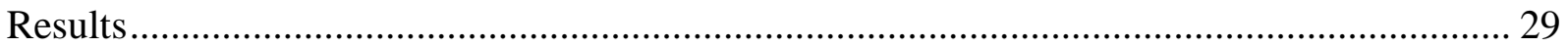

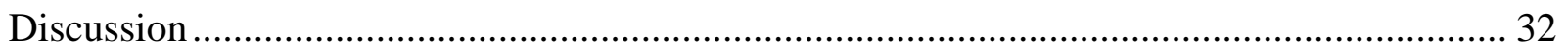

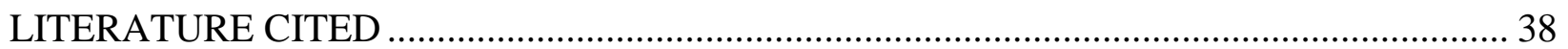

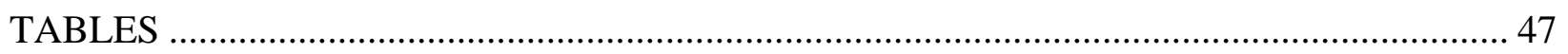

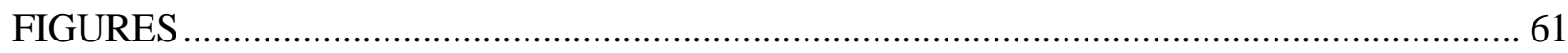




\section{LIST OF TABLES}

Table 1. Subpopulations represented in each sample used in STRUCTURE analysis, construction of a neighbor joining tree, and for pairwise comparison of $\mathrm{F}_{\mathrm{ST}}$. List of E. osburni collection sites enumerated to correspond with the map of the study area. The total number of pure E. osburni identified at each site is provided. The subpopulation names are abbreviated versions of the collection site names.

Table 2. Pairwise $F_{\text {ST }}$ values between the subpopulations in the Greenbrier and Gauley River drainages. Estimates in bold were statistically significant after sequential Bonferroni correction for multiple comparisons $(\mathrm{p}<0.0001)$.

Table 3. Pairwise $F_{\text {ST }}$ values between subpopulations within the Greenbrier River drainage. Estimates in bold were statistically significant after sequential Bonferroni correction for multiple comparisons $(\mathrm{p}<0.0001)$.

Table 4. Pairwise FST values between subpopulations within the Gauley River drainage. Estimates in bold were statistically significant after sequential Bonferroni correction for multiple comparisons $(\mathrm{p}<0.0001)$.

Table 5. Measures of diversity in both populations. Effective population size $\left(\mathrm{N}_{\mathrm{e}}\right)$ was calculated using the Linkage Disequilibrium method in NeEstimator with Jackknife confidence intervals (Do et al. 2014). Allelic richness, observed heterozygosity $\left(\mathrm{H}_{\mathrm{O}}\right)$, and expected heterozygosity $\left(\mathrm{H}_{\mathrm{E}}\right)$ were calculated using FSTAT (Goudet 1995).

Table 6. Summary of E. osburni stocking events into Camp Creek and the Little Bluestone River from 2018 and 2019.

Table 7. Summary of E. osburni collections for reintroduction with the number of hybrids found at each site.

Table 8. Measures of genetic diversity in all subpopulations of the Greenbrier River population with the total number of individuals in each subpopulation. Allelic richness observed heterozygosity $\left(\mathrm{H}_{\mathrm{O}}\right)$, and expected heterozygosity $\left(\mathrm{H}_{\mathrm{E}}\right)$ were calculated using GenAlEx (Peakall and Smouse 2012).

Table 9. Pairwise FST values between the Greenbrier River drainage population and reintroduced Camp Creek and Little Bluestone River populations. Estimates in bold were statistically significant with an adjusted nominal level $(5 \%)$ for multiple comparisons ( $\mathrm{p}<0.01667)$.

Table 10. Measures of genetic diversity in all populations. Allelic richness observed heterozygosity $\left(\mathrm{H}_{\mathrm{O}}\right)$, and expected heterozygosity $\left(\mathrm{H}_{\mathrm{E}}\right)$ were calculated using GenAlEx (Peakall and Smouse 2012).

Table 11. Land cover composition (\%) for each watershed. Classes were created by NRAC statewide spectral classification for West Virginia using geographic object-based image analysis (GEOBIA), random forest (RF) machine learning, and National Agricultural Imagery Program (NAIP) orthophotography for mapping general land cover across the entire state. The percentage of each generalized category is visualized in Figure 10. 
Table 12. Percentage of each land cover class in the $100 \mathrm{~m}$ buffer around all streams in each watershed. The land cover classes that comprise Forested, Development, and Agriculture can be found in Table 11. Water was excluded because it represented the mainstem of the stream and not the riparian area.

Table 13. Watershed area and elevation with a comparison of watershed characteristics related to development between the CCW, the LBRW, and the UGW.

Table 14. Comparison of watershed characteristics related to resource extraction and potential impacts to water quality between the CCW, the LBRW, and the UGW. 


\section{LIST OF FIGURES}

Figure 1. Records of E. osburni prior to 1990 in Camp Creek and the mouth of the Little Bluestone River.

Figure 2. E. osburni collection locations. The numbers correspond to information contained in Table 2. Squares represents sites in the Gauley River drainage and circles represent sites in the Greenbrier River drainage.

Figure 3. Results from application of the Evanno et al. (2005) method for determining the most likely number of genetic clusters (K) in STRUCTURE. DeltaK = change in log probabilities of each $\mathrm{K}$, mean $(|\mathrm{L} "(\mathrm{~K})|)=$ mean log likelihood among replicates for each value of $\mathrm{K}, \mathrm{sd}(\mathrm{L}(\mathrm{K}))$ = standard deviation of log likelihoods among replicates for the same K.

Figure 4. STRUCTURE diagram result from the most likely $(K=2)$ number of distinct genetic clusters. The numbers on the $\mathrm{x}$-axis correspond to subpopulations in Table 2 . The colors correspond to each of the two distinct genetic clusters. Each bar is an individual and the proportion of color in the bar corresponds to the probability of posterior assignment to that population.

Figure 5. Neighbor-joining tree constructed using genetic distance ( $\mathrm{D}_{A}$; Nei et al. 1983).

Figure 6. Satellite view of the CCW and the LBRW boundaries with their relation to the Bluestone and New Rivers that flow south to north. The mainstem rivers are light blue. Bluestone Lake is maintained by the Bluestone Dam and blocks E. variatum from moving into the Bluestone River drainage and the lower middle New River watershed.

Figure 7. Map of the three watershed locations in West Virginia including major rivers in the New River Drainage. Light grey boundaries represent HUC-8 watershed boundaries where E. osburni is present. Major dams are barriers to the dispersal of E. variatum.

Figure 8. Mean within population pairwise relatedness (r) values for each population (Queller and Goodnight 1989). Upper (U) and lower (L) confidence limits bound the $95 \%$ confidence interval about the null hypothesis of 'No Difference' across the populations as determined by permutation. Upper and lower error bars bound the $95 \%$ confidence interval about the mean values as determined by bootstrap resampling.

Figure 9. Land cover in the CCW and the LBRW from the NRAC statewide spectral classification for West Virginia using geographic object-based image analysis (GEOBIA), random forest (RF) machine learning, and National Agriculture Imagery Program (NAIP) orthophotography for mapping general land cover across the entire state.

Figure 10. Land cover summary for each watershed using pie charts with the percentage of each generalized land cover category from Table 11.

Figure 11. Land cover within $100 \mathrm{~m}$ of a stream to represent riparian zone land use.

Figure 12. West Virginia 2018 surface tax parcel data representing different landowner types (public, private, and large corporate landowners). 
Figure 13. Roads and Highways within the CCW and the LBRW based on roads mapped by Esri's StreetMaps North America dataset (Esri 2012a). This includes small rural paved and unpaved roads, local roads, county and state highways, and federal highways.

Figure 14. Resource extraction and transportation activities in the CCW and the LBRW. Abandoned oil and gas wells locations were found using the West Virginia Department of Environmental Protection database (WVDEP 2018). 


\section{Chapter 1: Introduction and Literature Review}

\section{Candy Darter (Etheostoma osburni)}

Darters are one of the most diverse and imperiled group of fishes in North America with more than 200 described species, 25 of which are listed under the U.S. Endangered Species Act. Among these endangered darters is the endangered Candy Darter (Etheostoma osburni; Hubbs and Trautman 1932). E. osburni is a narrowly endemic species native to the New River drainage of the upper Kanawha River basin in West Virginia and Virginia (Jenkins and Burkhead 1994). It has been extirpated from much of its historic range in West Virginia, restricting it to the Gauley and Greenbrier river drainages. In Virginia, there are only four isolated populations remaining (McBaine and Hallerman 2020).

E. osburni can be found in cool mountain streams and mid-sized rivers in the Kanawha River basin above Kanawha Falls. Based on habitat association studies, E. osburni adults prefer loose rubble and boulder substrate of high velocity riffle habitat, while juveniles may prefer lower velocity areas especially during the spawning season (Chipps et al. 1994; Dunn and Angermeier 2016). The species is particularly sensitive to stream embeddedness where watersheds with higher agricultural and urban development were associated with population extirpations (Dunn and Angermeier 2016; Dunn and Angermeier 2019). Benthic macroinvertebrates (primarily mayflies (Ephemeroptera)) comprise the majority of E. osburni's diet (Schoolcraft et al. 2007).

In addition to this restricted range, the species is jeopardized by introgressive hybridization with the closely related, invasive Variegate Darter (E. variatum; Kirtland 1840) (Switzer et al. 2007; Gibson et al. 2019). E. variatum occurs throughout the Ohio River drainage 
below Kanawha Falls (Stauffer et al. 1995), with the exception of the Wabash and Tennessee River systems (Hubbs and Black 1940). Introgressive hybridization is the incorporation of genes from one species into another species leading to a loss of one species' native alleles. It can cause species extinction when previously allopatric species come into secondary contact through genetic swamping where when one species' populations are progressively taken over by hybrids and individuals from the other species (Rhymer and Simberloff 1996; Todesco et al. 2016).

Kanawha Falls historically separated E. variatum and E. osburni, but by the 1990's, E. variatum populations had established above the falls, likely due to repeated bait bucket introductions. Natural hybridization is common between darters (Keck and Near 2009), but human-mediated introductions and hybridization may cause the extinction of E. osburni. Gibson et al. (2019) characterized the extent of hybridization and identified a hybrid swarm moving up the Greenbrier River drainage and throughout E. osburni's range. Populations in the Gauley (below Summersville Dam), Greenbrier, river drainages are experiencing introgressive hybridization and genetic swamping with E. variatum. Its limited range, numerous population extirpations and the threat of introgression led E. osburni being listed as endangered under the U.S. Endangered Species Act.

Population Genetics

Population genetic studies on endangered species are crucial to conservation planning. They are primarily concerned with identifying populations through genetic structure and characterizing the levels of genetic diversity amongst those populations. The structure of a species' populations can be used to identify conservation units and provide information that benefits reintroduction and captive breeding programs. 
Endangered and threatened darters can show a high degree of population structure within their narrow distributions. The threatened Okaloosa Darter E. okaloosae, for example, is restricted to a single watershed $\left(457 \mathrm{~km}^{2}\right)$ encompassing three bayous in Florida. Genetic analysis revealed a high level of differentiation between fish in the three bayous (Austin et al. 2011). Olsen et al. (2016) found significant genetic divergence at neutral loci between the two populations of the Fountain Darter E. fonticola in the San Marcos and Comal rivers in Texas that are separated by only $200 \mathrm{~km}$ of river distance. The Comal population was sourced from the San Marcos population after extirpation only 40 years ago. Both of the previous studies recommend treating these distinct populations as separate management units (MUs). Brogdon et al. (2003) devote most of their discussion to the MUs of the Tallapoosa Darter. They sequenced the cytochrome b region to determine genetic structure and identified four MUs whose loss would raise conservation concern.

Genetic diversity is measured with levels of heterozygosity, allelic richness, effective population sizes, previous bottlenecks, and levels of inbreeding and relatedness. High levels of inbreeding and relatedness in small populations can lead to loss of heterozygosity and decreased population fitness (Reed and Frankham 2003). Bottlenecks occur when a population size quickly declines, and they have effects on population structure and diversity. Finding evidence of a bottleneck in populations may help explain why effective population sizes are small. Bottlenecks can result in a loss of genetic diversity and a decrease in heterozygosity. E. osburni's range has been greatly reduced and population sizes are small. Small fragmented populations tend to have an increased chance of inbreeding and loss of diversity through genetic drift, which poses a threat to long-term persistence. To facilitate informed management and recovery plans for $E$. osburni's long-term survival, more extensive study of its population genetics is needed. 
The USFWS Candy Darter ruling alludes to the need to define conservation units: "The available genetic data for the Candy Darter indicate that the Upper and Lower Gauley River metapopulations are different from the Greenbrier metapopulation. While we have no information regarding the evolutionary significance of these genetic differences to either metapopulation, the loss of either metapopulation would represent a loss to the species' genetic diversity" (U.S. Department of the Interior 2018). Genetics-based management uses comprehensive population genetic data to delineate conservation units. Conservation units can be broadly defined as a population or group of populations within a species that warrant separate management. Examples of intra-specific conservation units include, but are not limited to, recovery units (RUs), distinct population segments (DPSs), evolutionary significant units (ESUs), and management units (MUs). DPSs and RUs were defined by the managers at the USFWS while ESUs and MUs were defined by researchers. These conservation units have explicit criteria and are used to guide future research objectives and recovery goals.

\section{Reintroductions}

There have been recent reintroduction efforts focused on establishing E. osburni populations in areas where they have been extirpated. In October of 2018, Candy Darters were collected by the West Virginia Division of Natural Resources (WVDNR) from the Greenbrier River drainage for reintroduction and captive breeding. The Greenbrier drainage population was chosen to start this initiative in an attempt to save some individuals from introgressive hybridization with the incoming hybrid swarm (Gibson et al. 2019). Additionally, the Greenbrier River drainage population is robust and diverse which may make it more resilient to the potential deleterious effects of small reintroduction population size (Gibson 2017; Chapter 2). 
In October 2018, E. osburni were collected from the Little River East Fork Greenbrier River, East Fork Greenbrier River and West Fork Greenbrier River, for reintroduction and captive breeding. Genetic samples were taken from all introduced individuals before reintroduction to ensure no E. variatum or hybrids were introduced. On December 4, 2018, 82 of these Candy Darters were stocked for reintroduction into Camp Creek in the Bluestone River drainage. The WVDNR chose Camp Creek for multiple reasons. First, there is evidence of a historic population in the mainstem (Figure 1). Additionally, a large section of Camp Creek lies within the protected area of Camp Creek State Park and Forest where there is good quality habitat and substrate for E. osburni (N. Owens, pers. comm.). The remaining 36 Candy Darters from the initial collection were being held in the White Sulphur Springs Fish Hatchery for possible captive propagation, but they were eventually released into Camp Creek in the summer of 2019 .

In November 2019, Candy Darters were collected in the East Fork Greenbrier River under the U.S. Forest Service's collection permit. Most of these individuals were reintroduced to the Little Bluestone River. E. osburni have been extirpated from the Bluestone River, but there are historic records of individuals at the mouth of the Little Bluestone, so it was chosen as a suitable area for new population establishment (Figure 1).

E. variatum expansion into Camp Creek and the Little Bluestone River is blocked by the Bluestone Dam and Bluestone Lake. However, there is still a possibility of human-mediated introductions into the lake. In an attempt to reduce the chances of these introductions, the West Virginia Division of Natural Resources has imposed regulations that include (1) making it illegal to possess any darter for bait, (2) prohibiting the use of fish as bait (dead or alive) in waters with 
extant E. osburni populations, and (3) prohibiting the release of any fish in water other than the location it was captured (WVDNR 2020).

\section{Thesis Objectives}

Chapter 2 of this thesis will characterize the population genetic structure of E. osburni throughout West Virginia, estimate and compare genetic diversity between distinct populations, and define the conservation units. Chapter 3 of this thesis will assess whether the reintroduced E. osburni populations adequately capture the genetic diversity of the source population and whether the landscape characteristics associated with the sites of introduction are similar to those of the source site. 


\section{Chapter 2: Population genetics and conservation units of the Candy Darter (Etheostoma osburni) in West Virginia}

Introduction

Population genetic studies on endangered species are crucial to their recovery. Assessments of population structure and the subsequent diversity of those populations can then be used to identify conservation units for management and recovery. This importance is highlighted by the U.S. Fish and Wildlife Service (USFWS) specifically calling for evaluation of a species' population genetics in their Species Status Assessments (SSAs) where they focus on the "3Rs": resiliency, redundancy, and representation (USFWS 2016). If populations within a species can tolerate stochastic disturbance events that affect their demographics and habitat quality, they are resilient. A species has adequate redundancy when it contains multiple, connected resilient populations that can withstand catastrophic events. Representation involves a species' ability to adapt to changing environments over time and is explicitly measured by evaluating the genetic diversity within and among populations across the species' range. Using the "3Rs" approach is especially valuable when evaluating the status of imperiled freshwater species because they tend to show a high degree of structure and diversity in lotic systems.

The USFWS ruling on the Candy Darter alludes to the need for a population genetics study with a focus on conservation units by stating: "The available genetic data for the Candy Darter indicate that the Upper and Lower Gauley River metapopulations are different from the Greenbrier metapopulation. While we have no information regarding the evolutionary significance of these genetic differences to either metapopulation, the loss of either metapopulation would represent a loss to the species' genetic diversity" (U.S. Department of the Interior 2018). Clearly defining distinct E. osburni populations using genetic tools will contribute to understanding the evolutionary significance and diversity within the species. 
Genetics-based management uses these comprehensive genetic data to delineate conservation units. Examples of intra-specific conservation units include, but are not limited to, recovery units (RUs), distinct population segments (DPSs), evolutionary significant units (ESUs), and management units (MUs). Conservation units guide future research objectives and recovery goals. Under the ESA, protection can be granted to species, subspecies, and DPSs. The USFWS defines a DPS as "a vertebrate population or group of populations that is discrete from other populations of the species and significant in relation to the entire species." (U.S. Department of the Interior and U.S. Department of Commerce 1996). DPSs can be assigned different ESA classifications (endangered or threatened) to address regional issues without needing to list the species throughout its entire range.

The USFWS also uses RUs to address the different needs of species across its range. They are "a management sub-unit of the listed entity, geographically or otherwise identifiable, that is essential to the recovery of the entire listed entity; conserves genetic or demographic robustness, important life history stages, or other features for long-term sustainability of the entire listed entity." (National Marine Fisheries Service 2018). They should encompass the entire range of the species and all RUs have to be recovered for the species to be delisted. Their criteria are not as strict as DPSs. RUs are an underutilized conservation unit with only $2.9 \%$ of listed species having them as of January 2018 (Evans et al. 2020).

Alternatively, ESUs and MUs were coined and defined by researchers, and like the term "species," there is no scientific consensus on the definition of these terms, or the criteria used for identifying them within populations. Waples (1991) gave the first formal definition wherein an ESU is a population that is reproductively isolated from other conspecific populations and represents an important component in the evolutionary legacy of the biological species. 
Reproductive isolation was inferred from geography and evolutionary significance was evaluated with genetic and ecological data.

Moritz (1994) notably defined ESUs as populations that are reciprocally monophyletic in their mitochondrial DNA and show significant divergence in their nuclear DNA. Adding to Moritz's (1994) definition that was based on genetics alone, Crandall et al. (2000) emphasize that ESUs within a species should lack "ecological exchangeability" and "genetic exchangeability." ESUs are ecologically exchangeable when there are minimal differences in characteristics like morphology, habitat, and selection pressures. Ecological exchangeability is rejected if there is differentiation between populations due to genetic drift or natural selection. Populations have genetic exchangeability if there is gene flow between them. Fraser and Bernatchez (2001) argue for an adaptive approach to evolutionary conservation where the criteria used to define an ESU are not rigid, but the most relevant to the species of concern. They suggest that researchers focus on finding differences in adaptive variation and identify historic isolation between populations. Newer genetic studies have criticized using only neutral genetic markers (e.g. microsatellite loci) in defining ESUs (de Guia and Saitoh, 2007; Funk et al. 2012). They argue that adaptive loci (e.g. single nucleotide polymorphisms), unlike neutral loci, can detect alleles under selection making them a better metric for evolutionarily significance.

With less strict criteria, MUs are defined by demographic and geographic independence. They were defined by Moritz (1994) as "populations with significant divergence of allele frequencies at nuclear or mitochondrial loci, regardless of the phylogenetic distinctiveness of the alleles." Moritz (1999) expanded his definition to say that "MUs represent demographically independent populations, i.e., the functional components of the (usually larger) ESU.” MUs may not show long-term independent evolution or strong adaptive differentiation. More recently, 
MUs have been characterized by their degree of genetic divergence based on dispersal rates and not the ability to reject panmixia (Palsbøll et al. 2007). Management of MUs is a balance between the possible deleterious effects of isolation and small population size and the loss of genetic distinctness by introducing gene flow between MUs.

Previous research on E. osburni genetics has primarily focused on hybridization and population genetic analyses were limited. In terms of the E. osburni populations in West Virginia, Switzer et al. (2007) found some evidence of demographic differences between populations in the Gauley and Greenbrier River drainages using mitochondrial DNA. The genetics of E. osburni in the Greenbrier River drainage were characteristic of a large and stable population through time, while the Gauley drainage genetics were consistent with a dramatic decline and subsequent expansion. The authors attribute this to the allopatric fragmentation of the two rivers as they are separated by approximately $600 \mathrm{~km}$ of river distance that includes the barrier created by Summersville Dam (Figure 1).

Gibson (2017) detected high levels of genetic distinction between individuals in the Greenbrier and Gauley River drainages $\left(\mathrm{n}=335 ; \mathrm{F}_{\mathrm{ST}}=0.144(\mathrm{P}=0.017)\right)$ with a small number of microsatellite loci ( $n=5)$. In addition, Gibson (2017) found evidence of morphologic distinctness between individuals from the Gauley and Greenbrier drainages. While the ranges overlapped, the number of pectoral fin rays, anal fin rays, scales below the lateral line, scales along the lateral line, and scales around the caudal peduncle differed modally. One of the largest differences was that $64 \%$ of the individuals in the Greenbrier population possessed embedded breast squamation compared to $12.5 \%$ of individuals in the Gauley population (Gibson 2017).

Assessment of E. osburni population genetic structure and diversity with more individuals and loci will provide further information on distinctness, possible sub-structuring and 
evolutionary significance between the Gauley and Greenbrier river populations. The objectives of this study were to characterize the population genetic structure of E. osburni throughout West Virginia, estimate and compare genetic diversity between distinct populations, and define the conservation units of the species.

Methods

Collection and Preservation

Tissue samples were collected from 484 individuals at 19 sites in West Virginia (Table 1; Figure 2) by the West Virginia Division of Natural Resources (WVDNR). Biologists with backpack electrofishing units and seines captured individuals, then clipped their right pelvic fin for genetic analysis. Fins were preserved in $99 \%$ ethyl alcohol and the fish were released back into their streams. Tissue samples from individuals collected in 2014, 2016, 2018, and 2019 were used in this study.

\section{Laboratory Techniques}

Switzer et al. (2008) developed a set of 15 polymorphic microsatellite DNA markers for examining genetic variation within populations of E. osburni and E. variatum. We used 13 for this study (excluding Eos-D116 and Eos-C108). There were five loci (Eos-C2, Eos-C3, Eos-C6, Eos-C112, and Eos-C117) that did not overlap in allele size between the two species, so we used them to diagnose pure E. osburni, pure E. variatum, and hybrids. Only individuals with $100 \%$ E. osburni alleles were included in further analyses. All the individuals that were identified as pure E. osburni by the microsatellite loci had a 486-bp region of the mitochondrial cytochrome b (cyt b) region sequenced to ensure no cryptic E. variatum hybrids were included in this study. DNA was extracted with the Promega SV 96 Genomic DNA Purification System following a modified 
version of the "Animal Tissues" protocol. Approximately $4 \mu \mathrm{g}( \pm 2 \mu \mathrm{g}$; or approximately $1 \mathrm{~mm} \mathrm{X}$ $2 \mathrm{~mm}$ ) of pelvic fin tissue per specimen was prepared in each well of a 96-well plate for a 16hour digestion at $55^{\circ} \mathrm{C}$. The elution process consisted of two elutions with the first using $100 \mu \mathrm{L}$ and the second using $50 \mu \mathrm{L}$ (for a total elution volume of $150 \mu \mathrm{L}$ ) and was performed with a combination of vacuum and centrifugation. Concentrations of extracted DNA were quantified with a NanoDrop Lite spectrophotometer. DNA elutions were diluted to $10 \mathrm{ng} / \mu \mathrm{L}$.

Components of mitochondrial polymerase chain reaction (PCR) consisted of $5 \mathrm{X}$ buffer, $200 \mu \mathrm{M}$ dNTPs, $20 \mu \mathrm{M}$ forward and reverse primer (forward 5'-

CACCATCGAGGCTAGCAAGG-3'; reverse 5'-ATGGATCTGAGGGGGCTTCT-3'), 0.005 units/ml Taq polymerase and 70 ng DNA extract for a final volume of $25 \mu 1$. The mitochondrial cyt b gene was amplified using a "touchdown" method with an initial denaturation stage of $95^{\circ} \mathrm{C}$ for 2 minutes followed by 20 cycles of $95^{\circ} \mathrm{C}$ for 1 minute, $60^{\circ} \mathrm{C}$ for 1 minute, and $72^{\circ} \mathrm{C}$ for 2 minutes where the $60^{\circ} \mathrm{C}$ annealing temperature decreased by $0.5^{\circ} \mathrm{C}$ every cycle. The first 20 cycles were followed by another 20 cycles of $95^{\circ} \mathrm{C}$ for 1 minute, $48^{\circ} \mathrm{C}$ for 1 minute, and $72^{\circ} \mathrm{C}$ for 2 minutes. DNA was sequenced using an ABI Model 3130XL Genetic Analyzer. We compared the study sequences to GENBANK isolates of both species (NCBI nucleotide database; HQ128185.1, AY964691.1, AY964690.1, AY964688.1, AY964687.1, AF289266.1) and none had E. variatum mtDNA.

The five diagnostic loci and the remaining eight loci were used to determine the population genetic structure and genetic diversity of pure E. osburni. DNA was amplified using three multiplex PCR reactions (1: Eos-C124, Eos-D11, Eos-C207, Eos-C208; 2: Eos-D10, EosD108, Eos-D107 and Eos-D131; 3: Eos-C2, Eos-C3, Eos-C6, Eos-C112, and Eos-C117). Components of microsatellite PCR consisted of 2X QIAGEN multiplex PCR master mix, $0.2 \mu \mathrm{M}$ 
each of forward and reverse primer, and $20 \mathrm{ng}$ of DNA extract in a $10 \mu \mathrm{l}$ reaction. A thermal cycler was used to perform PCR with an initial denaturation stage of $95^{\circ} \mathrm{C}$ for 15 minutes followed by 25 cycles of $94^{\circ} \mathrm{C}$ for 30 seconds, $57^{\circ} \mathrm{C}$ for 90 seconds, and $72^{\circ} \mathrm{C}$ for 60 seconds, then a final extension stage of $60^{\circ} \mathrm{C}$ for 30 minutes. PCR products were sent to the WVU Genomics Core facility for capillary electrophoresis on an ABI 3130xl system. GeneMarker (Hulce et al. 2011) was used to visualize and score the fragments and they were manually verified for each individual.

\section{Population Genetic Analyses}

In the following genetic analyses, individuals were grouped by the mainstem river or creek where they were collected for a total of 19 collection sites grouped into 14 subpopulations (Table 1). The Gauley River was split between its upper and lower section because the Summersville Dam is a barrier to fish passage. The lower Gauley population exists below the dam and cannot naturally migrate between the other subpopulations in the drainage.

The potential for null alleles was investigated with MICROCHECKER v2.2.3 (Van Oosterhout et al. 2003). Microsatellite loci were tested for Hardy-Weinberg equilibrium (HWE) with the program GENEPOP v4.2 (Raymond and Rousset, 1995) for the 14 subpopulations.

Pairwise $F_{S T}$ fixation indices were calculated between the subpopulations with the program ARLEQUIN (Excoffier et al. 2005) to determine their degree of genetic differentiation. Delineating population differentiation using F $_{\text {ST }}$ values followed Weir and Cockerham (1984) using 1000 permutations in ARLEQUIN. Significance level was calculated using sequential Bonferroni correction for multiple comparisons (Rice 1989). 
A Bayesian clustering analysis using the program STRUCTURE (Pritchard et al. 2000) was used to identify distinct populations of E. osburni. Ten independent runs were performed for each K from K = 1 to K = 17 with 100,000 Markov Chain Monte Carlo (MCMC) iterations and a burn-in period of 100,000. The default settings which included correlated allele frequencies, assumed admixture, and no prior information were used. STRUCTURE HARVESTER v0.6.94 was used to visualize the STRUCTURE results; the $\Delta \mathrm{K}$ method of Evanno et al. (2005) and the $\mathrm{K}$ with the highest likelihood and least variance between runs were used to determine the number of $\mathrm{K}$ at the highest level of genetic partitioning (Earl and vonHoldt 2012). An iterative, hierarchical method to investigate substructure was implemented. A subsequent STRUCTURE analysis with 10 independent runs for each $\mathrm{K}$ from $\mathrm{K}=1$ to $\mathrm{K}=13$ using the same parameters as above was conducted on clusters identified in the first run. This method was repeated until there was no other substructure identified. A neighbor-joining tree based on genetic distance $\left(D_{A} ;\right.$ Nei et al. 1983) was constructed with the program POPTREE2 with 10,000 bootstrap replications to visualize the phylogenetic relationships between the populations (Takezaki et al. 2010).

Once genetically distinct populations were identified, individuals were pooled into these groups for genetic diversity calculations. Allelic richness, observed heterozygosity $\left(\mathrm{H}_{\mathrm{O}}\right)$, expected heterozygosity $\left(\mathrm{H}_{\mathrm{E}}\right)$, and relatedness (Queller and Goodnight 1989) were calculated for each population and compared using 10,000 permutations in FSTAT. These diversity measures were also calculated for each subpopulation using GenAlEx (Peakall and Smouse 2012). We calculated effective population size $\left(\mathrm{N}_{\mathrm{e}}\right)$ using the linkage disequilibrium method (random mating) (NeEstimator V2.1; Do et al. 2014) and tested for evidence of a bottleneck with the twophase model and the Sign, Wilcoxon, and Mode-Shift tests (variance= 0.30, proportion of SMM 
$=70.00 \%$; BOTTLENECK; Cornuet and Luikart 1996) to evaluate genetic diversity of the $E$. osburni populations.

Results

There were no significant departures from HWE in the subpopulations at each locus following sequential Bonferroni correction. All subpopulations in the Gauley River drainage were fixed for a single allele at Eos-C3. Three loci had potential null alleles, each only in one subpopulation (Eos-C124 (L.R.E.F Greenbrier R), Eos-D10 (W.F. Greenbrier R.), and EosD107(W.F. Greenbrier R.). Without evidence of deviations from HWE, these loci were kept in the dataset. At locus Eos-C2, two subpopulations showed evidence of stutter, so it was only used to diagnose hybrids, then removed from the dataset and subsequent analyses. The rest $(\mathrm{n}=12)$ of the loci were kept in the dataset.

The Gauley and Greenbrier subpopulations were highly genetically differentiated with a mean $F_{S T}=0.128$. Pairwise $F_{S T}$ values were calculated between the 14 subpopulations (Tables 2 -4). All between-drainage values were statistically significant (Table 2). There was low to moderate differentiation observed when comparing within drainage with 12 out of 16 values being significant within the Greenbrier drainage (Table 3) and 15 out of 28 values being significant in the Gauley drainage (Table 4). The highest statistically significant value in the Greenbrier drainage was observed between Deer Creek and Knapp Creek $\left(F_{S T}=0.055\right)$, while the lowest was between Sitlington Creek and L.R.E.F Greenbrier River $\left(\mathrm{F}_{\mathrm{ST}}=0.013\right)$. The highest statistically significant value in the Gauley drainage was observed between Cranberry River and Upper Gauley River $\left(F_{S T}=0.072\right)$ and the lowest was between the Cherry River and Laurel Creek $\left(\mathrm{F}_{\mathrm{ST}}=0.019\right)$. 
A STRUCTURE analysis of the 508 individuals from the Greenbrier and Gauley River drainages indicated the most likely number of distinct clusters was $K=2$ (Figure 3) with distinct populations split clearly by drainage (Figure 4). The subsequent STRUCTURE analyses performed after the dataset was split by drainage found no evidence of substructuring within the Greenbrier or Gauley population. The neighbor-joining tree supports these conclusions with $100 \%$ of 10,000 generated trees supporting monophyly amongst the subpopulations of the Greenbrier and Gauley drainages (Figure 5). There was not strong bootstrap support for any of the relationships between subpopulations within each drainage, except the E.F. Greenbrier R. and the L.R.E.F. Greenbrier R. pairing being present in $79 \%$ of trees. The lack of support indicates low levels of substructure within each drainage, which corroborates the STRUCTURE results.

In the following analyses, individuals were grouped by drainage to represent distinct populations (Greenbrier: $n=314$; Gauley: $n=170$ ). The Gauley population had lower levels of genetic diversity in terms of effective population size $\left(\mathrm{N}_{\mathrm{e}}\right)$, allelic richness, and heterozygosity $\left(\mathrm{H}_{\mathrm{O}}\right.$ and $\left.\mathrm{H}_{\mathrm{E}}\right)(\mathrm{p}, 0.0033$; Table 5). Neither population showed evidence of a recent bottleneck under the two-phase model for the Sign, Wilcoxon, and Mode-Shift tests. Relatedness between individuals in the Gauley population was higher than in the Greenbrier population, but not significantly so (Table 5).

\section{Discussion}

\section{Population Genetics}

Establishing E. osburni population genetic structure and diversity is the first step toward recovery of the species. Reintroduction and captive breeding plans require comprehensive genetic knowledge to succeed. We aimed to characterize E. osburni structure and diversity throughout its range in West Virginia and use that information to delineate conservation units. 
Candy Darters in the Gauley and Greenbrier drainages have been separated long enough to result in high levels of genetic distinctness based on our FST calculations, STRUCTURE analysis and neighbor-joining tree construction, affirming the preliminary findings of Switzer (2007) and Gibson (2017).

There was no evidence for substructure within either drainage. It is possible that substructure is present, but not observed because all fish were fin clipped outside their spawning season. This is illustrated with migratory species like anadromous fish. Genetic and location data taken from fish in the ocean will show one large population that lacks substructure. If this information is taken during freshwater-spawning, it could reveal many distinct populations. There is little information on E. osburni's dispersal capacity, but given our results, dispersal rates may be larger than expected. There are a limited number of movement studies on darters because their small size makes mark-recapture studies difficult. With the advent of visible implant elastomer (VIE) tagging, there may be an increase in movement studies on small riverine fish (Holt et al. 2013; Weston and Johnson 2008; Holcomb et al. 2020). The rapid spread of introduced darters may illustrate our underestimation of darter movement capabilities. $E$. variatum, E. caeruleum, and E. blenniodes have all been introduced beyond their native range and swiftly colonized their new watersheds (Gibson et al 2019; Cessna et al. 2014; Beneteau et al. 2012), indicating the possibility for dispersal capabilities that may be higher than expected.

The Summersville Dam has separated the lower Gauley subpopulation from the rest of the drainage since its completion in 1966 (Figure 1). However, genetic differentiation between the lower and upper Gauley subpopulation was low and not significant $\left(\mathrm{F}_{\mathrm{ST}}=0.009\right)$. For fish, barriers can increase population structure and decrease diversity (Horreo et al. 2011; Gouskov and Vorburger 2016), but the strength of this trend can be species- and barrier-specific (Ruzich et 
al. 2019; Euclide et al. 2018). Blanchet et al. (2010) found that the genetic effects of fragmentation were smaller for small bodied fish. The Summersville Dam is 54 years old ( $18 E$. osburni generations), which may not be long enough to detect population structure especially if the population has a high effective population size. The lack of structure may also be attributed to movement of adults or juveniles. Human-mediated introduction occurred nearby and lead to the spread of E. variatum, so it is possible that anglers have moved E. osburni below the dam. Bait-bucket introductions of E. variatum above Summersville Dam would pose an existential threat to this population.

The Greenbrier population had higher levels of genetic diversity over all metrics. These differences could reflect different demographic forces present in both populations. Switzer et al. (2007) found some evidence of genetic divergence between the Gauley and Greenbrier populations of E. osburni using nuclear and mitochondrial DNA. Mitochondrial cytochrome b sequences revealed that the populations have experienced different demographic events. The Gauley River results were consistent with a population bottleneck and recent expansion. The Greenbrier River results were consistent with a large, stable population over time.

Their difference in diversity may be related to the geology and history of the watersheds. The Gauley River and its tributaries lie in the Appalachian Plateau, while the Greenbrier River drainage lies in a boundary zone between the Appalachian Plateau and the Valley and Ridge region. The Valley and Ridge region and boundary zone have a larger diversity of bedrock types, including limestone, which may help buffer it from acidification (Hack 1973). The Appalachian Plateau has primarily sandstone and siltstone bedrock types which provide little buffering capacity from acidification (Hack 1973; Strager 2019). The WVDNR has used limestone sand in the Gauley River drainage to help reduce acidification (Clayton and Menendez 1996). In 
addition, the Gauley River drainage contains more coal mining activity and oil/gas wells (Strager 2019). The Allegheny Plateau has more seasonably variable flows compared to the Valley and Ridge region which has well developed aquifers and stable flows (Messinger and Hughes 2000). The Gauley River drainage has a higher proportion of impaired streams to total streams compared to the Greenbrier when the impaired stream length is divided by total stream length in the watershed (WVDEP 2019). Poor water quality caused by acidification and resource extraction may have caused high mortality (local extinctions) and smaller population sizes in the Gauley River drainage, leading to lower genetic diversity. There are a multitude of other factors that likely affect genetic diversity that could be investigated including landscape, river, and community level characteristics.

The 50/500 or 100/1000 rule for effective population size, although debated, serves as a baseline for conservation biologists (Franklin 1980; Frankham et al. 2014a; Franklin 2014; Frankham et al. 2014b). In the short term, a population needs an effective population size $>50$ or 100 to avoid the deleterious effects of inbreeding and be viable in the short term and $>500$ or 1000 to maintain evolutionary potential in the long term. The exact numbers are debated because predicting levels of inbreeding and drift do not always incorporate natural selection. These numbers are likely different depending on the life history characteristics of the species in question. The cost of attaining an effective population size of 1000 for an imperiled population may outweigh the benefits if it does not make a difference. Regardless, larger effective population sizes are better than smaller ones. Both populations have an $\mathrm{N}_{\mathrm{e}}>50$, but the Gauley's $\mathrm{N}_{\mathrm{e}}$ is lower than 500 and the lower confidence interval for the Greenbrier's $\mathrm{N}_{\mathrm{e}}$ is less than 500 . Higher diversity of the Greenbrier population may make it more resilient to subsequent 
reintroduction and captive breeding efforts. Translocations have focused on the Greenbrier population because it faces the most imminent threat from introgression with E. variatum.

\section{Conservation Units}

The USFWS recognizes conservation units (DPSs and RUs) to subdivide species in order to guide their listing decisions and recovery plans. Population distinctness can include physical, physiological, ecological, or behavioral factors and population significance can be measured using genetics or other unique characteristics. These populations might be on different evolutionary trajectories, have differences in demographics or differences in conservation needs. DPSs are appropriate for wide-ranging species with discrete and separate subunits. Because DPSs can have different listings (threatened or endangered) within a species, they are useful for species where population segments differ in their conservation need. E. osburni is endangered throughout its entire range, so DPS designations are moot, even though its populations are clearly separate and distinct.

RUs are useful for species where the whole species is under threat of extinction, but identifiable subunits face different threats and need separate recovery plans. All RUs must be recovered for the species to be delisted. The two West Virginia populations are good candidates for separate RUs because they are genetically and geographically distinct and are both essential to preserve the genetic robustness of the species. The Gauley and Greenbrier populations are separated by over $600 \mathrm{~km}$ of river distance, making them geographically identifiable. The Greenbrier faces a rapid expansion of E. variatum and E. variatum x E. osburni hybrids moving up the drainage (Gibson et al. 2019). E. variatum has not established in the Gauley River drainage above Summersville Dam, so this population is not yet threatened by genetic 
swamping, but the Gauley population has suffered from subpopulation loss and may eventually suffer some of the deleterious effects of low genetic diversity.

Outside the framework of the ESA, researchers divide species into ESUs and/or MUs. There is some evidence that the two E. osburni populations in West Virginia represent two ESUs. While our study only used neutral markers, the high levels of distinctness between the populations indicate a long history of separation. Gibson (2017) found morphological differences in these two populations, which may be a proxy for adaptive differences. The two populations may be on their way to speciation, similar to the putative parapatric speciation of $E$. osburni and the Kanawha Darter (E. kanawhae; Raney 1941). Although there are no barriers like dams blocking the expansion of E. osburni, it is replaced by E. kanawhae in the Blue Ridge Plateau where the elevation is higher, and the substrates are more embedded (Dunn 2017). Geologic and geographic features can affect the distribution of E. osburni because they are sensitive to substrate embeddedness, stream depth, and water velocity (Dunn and Angermeier 2019).

MUs are subsets of ESUs where the different units may not be on different evolutionary trajectories or highly genetically distinct, but experience different demographic events and have different management needs. We found no substructure in either population, which gives us no strong evidence to further subdivide the Greenbrier and Gauley populations into management units. These populations should instead be treated as separate RUs under the Endangered Species Act because they represent two ESUs of the species. Both RUs would need to be fully recovered for the entire species to be delisted. Recovery units can be impactful when federal agencies are ensuring their actions do not pose a threat to the existence of a listed species or negatively impact its critical habitat according to Section 7 of the ESA (Evans et al. 2020). Typically, federal 
actions do not threaten a whole species, but if their actions threaten the survival of a recovery unit, they may be less likely proceed.

\section{Chapter 3: Genetic evaluation of reintroduced Candy Darters to Camp Creek and the}

\section{Little Bluestone River with a watershed level landscape analysis}

Introduction

Freshwater ecosystems are among the most diverse and imperiled in the world (Balian et al. 2008). Freshwater species face threats from overexploitation, pollution, flow modification, habitat destruction and invasive species (Dudgeon et al. 2006). Often, a combination of these threats can cause freshwater species to become endangered. Endangered species recovery and conservation involves maintaining and improving current populations and habitats while repatriating the species into suitable, historically occupied areas. Repatriation can be achieved through the translocation of wild-caught (in situ) individuals from one or more of the current populations and reintroducing them to a historically occupied area. It can also be achieved through propagation of captive (ex situ) individuals whose progeny is reintroduced to a historically occupied area. To increase the odds of a successful introduction, both methods require the evaluation of the source population's ability to sustain itself and the reintroduction site's ability to sustain the source populations (Armstrong and Seddon 2008; Dunham et al. 2011). Evaluation of a source population's genetics and reintroduction site habitat suitability are major components in the IUCN (1998) reintroduction guidelines. High genetic diversity of reintroduced populations and suitable habitat at the reintroduction sites are correlated with successful reintroduction outcomes for freshwater fish (Cochran-Biederman et al. 2014).

Population genetic techniques are a critical tool for both in situ and ex situ reintroduction plans (Weeks et al. 2011). First, the source population must be large enough to endure harvest 
and genetically diverse enough to produce viable translocated and captive populations (Montalvo et al. 1997; Schwartz et al. 2007). Population genetics can aid in captive breeding efforts by pairing individuals with minimum kinship and reducing the potential for inbreeding. Ongoing genetic monitoring can identify inbreeding and outbreeding depression in the reintroduced populations. Site selection is equally important. Sites that are not affected by the initial cause of species decline, contain few non-native species, and provide essential spawning habitat are more likely to lead to a successful introduction (Cochran-Biederman et al. 2014). Habitat and landscape features can affect a species' persistence at the microhabitat level and the watershed level (Roth et al. 1996; Rosenfeld 2003; Allan 2004; Nathan et al. 2018)

There have been recent reintroduction efforts focused on the endangered E. osburni. These efforts are informed by previous genetic and habitat research. E. osburni populations can be found in cool mountain streams and mid-size rivers in the Kanawha River basin above Kanawha Falls. Based on habitat association studies, E. osburni adults prefer loose rubble and boulder substrate of high velocity riffle habitat, while juveniles may prefer lower velocity areas especially during the spawning season (Chipps et al. 1994; Dunn and Angermeier 2016). The species is particularly sensitive to stream embeddedness where watersheds with higher agricultural and urban development were associated with population extirpations (Dunn and Angermeier 2016; Dunn and Angermeier 2019).

In October 2018, E. osburni were collected from the Little River East Fork Greenbrier River, East Fork Greenbrier River, and West Fork Greenbrier River for reintroduction and captive breeding. Genetic samples were taken from all introduced individuals before reintroduction to ensure no E. variatum or hybrids were included. On December 4, 2018, 82 of these Candy Darters were stocked for reintroduction into Camp Creek in the Bluestone River 
drainage (Table 6). The WVDNR chose Camp Creek for multiple reasons. First, there is evidence of a historic population in the mainstem (Figure 1). Additionally, a large section of Camp Creek lies within the protected area of Camp Creek State Park and Forest where there is good quality habitat and substrate for E. osburni (N. Owens, pers. comm.). The remaining 36 Candy Darters from the initial collection were being held in the White Sulphur Springs Fish Hatchery for possible captive propagation, but they were eventually released into Camp Creek in the summer of 2019 .

In November 2019, Candy Darters were collected from the East Fork Greenbrier River under the U.S. Forest Service's collection permit. The majority of these individuals were reintroduced to the Little Bluestone River where there are historic records of E. osburni at the mouth of the river where it meets the Bluestone River (Figure 1). E. variatum expansion into Camp Creek and the Little Bluestone River is blocked by the Bluestone Dam and Bluestone Lake (Figure 6).

Population genetic assessment and habitat quality evaluation are key components to reintroduction success. In order to address the ability of the reintroduced populations in Camp Creek and the Little Bluestone River to sustain themselves, the first objective of this chapter was to determine if these reintroduced populations adequately captured the genetic diversity of the source population. To evaluate the new habitat's ability to sustain the reintroduced population, the second objective of this chapter was to determine if the landscape characteristics of the Camp Creek and Little Bluestone watersheds are similar to the source sites of the East Fork and West Fork Greenbrier River Watersheds.

Methods

Field Techniques 
Individuals from the Greenbrier River drainage were collected in the fall of 2018 and 2019 for the purpose of reintroducing into watersheds that historically had extant E. osburni populations and do not currently contain populations of E. variatum. Many professionals and volunteers from the WVDNR, U.S. Forest Service, U.S. Fish and Wildlife Service, West Virginia Department of Environmental Protection (WVDEP), and West Virginia University were involved with the collection and reintroduction process. Biologists with backpack electrofishing units and seines captured individuals. The fish were placed into aerated and chilled coolers for transport to White Sulphur Springs National Fish Hatchery. At the hatchery, fish were given individual identifications, then their right pelvic fins were clipped and placed in $99 \%$ ethyl alcohol. Fin clips were sent to WVU for genotyping to ensure no hybrids or E. variatum were introduced. The fish were placed in aquariums that held two fish (one male and one female or one adult and one juvenile) each and were held until the genetic results on hybrid status were generated (Table 7). After genotyping, only genetically pure E. osburni were stocked to Camp Creek and the Little Bluestone River (Table 6).

E. osburni tissue samples $(\mathrm{n}=92)$ from the Greenbrier drainage population collected in 2014 and 2016 by WVDNR were used in this study to evaluate how well the reintroduced individuals captured the genetic diversity of the founder population (Table 8). Tissue collection was similar to above except fish were released after fin clipping.

\section{Laboratory Techniques}

Switzer et al. (2008) developed a set of 15 polymorphic microsatellite DNA markers for examining genetic variation within populations of E. osburni and E. variatum. We used 13 for this study (excluding Eos-D116 and Eos-C108). There were five loci (Eos-C2, Eos-C3, Eos-C6, Eos-C112, and Eos-C117) that did not overlap in allele size between the two species, so they 
were used to diagnose pure E. osburni, pure E. variatum, and hybrids. Only individuals with $100 \%$ E. osburni alleles were included in further analyses. DNA was extracted with the Promega SV 96 Genomic DNA Purification System following a modified version of their "Animal Tissues" protocol. Approximately $4 \mu \mathrm{g}( \pm 2 \mu \mathrm{g}$; or approximately $1 \mathrm{~mm} \mathrm{X} 2 \mathrm{~mm})$ of pelvic fin tissue per specimen was prepared in each well of a 96-well plate for a 16 -hour digestion at $55^{\circ} \mathrm{C}$. The elution process consisted of two elutions with the first using $100 \mu \mathrm{L}$ and the second using 50 $\mu \mathrm{L}$ (for a total elution volume of $150 \mu \mathrm{L}$ ) and was performed with a combination of vacuum and centrifugation. Concentrations of extracted DNA were quantified with a NanoDrop Lite spectrophotometer. DNA elutions were diluted to $10 \mathrm{ng} / \mu \mathrm{L}$.

The five diagnostic loci and the remaining eight loci were used to determine the population genetic structure and genetic diversity of pure E. osburni. DNA was amplified using three multiplex PCR reactions (1: Eos-C124, Eos-D11, Eos-C207, Eos-C208; 2: Eos-D10, EosD108, Eos-D107 and Eos-D131; 3: Eos-C2, Eos-C3, Eos-C6, Eos-C112, and Eos-C117).

Components of microsatellite PCR consisted of 2X QIAGEN multiplex PCR master mix, $0.2 \mu \mathrm{M}$ primer, and $20 \mathrm{ng}$ DNA extract in a $10 \mu \mathrm{l}$ reaction. A thermal cycler was used to perform PCR with an initial denaturation stage of $95^{\circ} \mathrm{C}$ for 15 minutes followed by 25 cycles of $94^{\circ} \mathrm{C}$ for 30 seconds, $57^{\circ} \mathrm{C}$ for 90 seconds, and $72^{\circ} \mathrm{C}$ for 60 seconds, then a final extension stage of $60^{\circ} \mathrm{C}$ for 30 minutes. PCR products were sent to the WVU Genomics Core Facility for capillary electrophoresis on an ABI 3130xl system. GeneMarker (Hulce et al. 2011) was used to visualize and score the fragments and they were manually verified for each individual.

\section{Genetic Evaluation}

The reintroduced population was evaluated by degree of differentiation from the Greenbrier drainage population. Indices of genetic diversity were compared between the Camp 
Creek, Little Bluestone and Greenbrier drainage population. Additionally, genetic diversity indices for the Greenbrier drainage subpopulations were calculated to determine their potential as source populations for ongoing management related to captive breeding and translocations.

The potential for null alleles was investigated with MICROCHECKER v2.2.3 (Van Oosterhout et al. 2003). Microsatellite loci were tested for Hardy-Weinberg equilibrium (HWE) with the program GENEPOP v4.2 (Raymond and Rousset, 1995) for the three populations (Camp Creek, Little Bluestone River, and Greenbrier). Pairwise F $_{\text {ST }}$ fixation indices were calculated between the populations with the program FSTAT (Goudet 2002) to determine their degree of genetic differentiation. Allelic richness, observed heterozygosity $\left(\mathrm{H}_{\mathrm{o}}\right)$, expected heterozygosity $\left(\mathrm{H}_{\mathrm{E}}\right)$, and relatedness (Queller and Goodnight 1989) were calculated for each population and each subpopulation within the Greenbrier population using GenAlEx (Peakall and Smouse 2012).

\section{Landscape Evaluation}

Geographic Information Systems (GIS) was used to determine if the landscape-level habitat characteristics of the Camp Creek and Little Bluestone watersheds are similar to the source sites of the East Fork and West Fork Greenbrier River Watersheds. All analyses were at the watershed level and the riparian buffer level using ArcMap 10.6 (ESRI 2017). Camp Creek and the Little Bluestone River are in southern West Virginia and part of the New River system (Figure 7). Both rivers are tributaries of the Bluestone River, which is a tributary of the New River, and lie within the Middle New 8-digit Hydrologic Cataloging Unit (HUC-8). The study area for this project was created using the USGS NHDPlus High Resolution Beta dataset (U.S. Geological Survey 2020). The Camp Creek watershed (CCW) study boundary was created using its HUC-12. This HUC-12 captures all of the area that drains to Camp Creek. The Little 
Bluestone River watershed (LBRW) is within a HUC-12, but it includes areas that do not drain to the Little Bluestone River. Using the NHDPlus catchment dataset, catchments within the HUC-12 that drained into the Little Bluestone River were selected and dissolved to form one watershed boundary polygon. Flowlines are vector data that represent stream center lines and they were also obtained using the NHDPlus High Resolution Beta dataset. The Upper Greenbrier River Watershed (UGW) is composed of the East Fork Greenbrier River and West Fork Greenbrier River watersheds and excludes the Greenbrier River proper. This watershed was created using two HUC-12 boundaries for the rivers. Mean elevation was calculated using a 30meter digital elevation model (DEM) from the National Elevation Dataset (U.S. Geological Survey 2016).

To evaluate the risks relative to their source watershed, data related to development, agriculture, and resource extraction were collected for the CCW, the LBRW, and the UGW. Development, agriculture, and resource extraction are known to impact streams in terms of water quality, flow, and temperature. The following data were summarized at the watershed level by clipping datasets to the watershed boundaries. Land cover data for the area was obtained from a dataset containing 25 different land cover classes that was based on aerial photography collected in 2016 (NRAC 2020). Analysis of the study areas' land cover composition was performed within watershed and stream buffer (100m). Land cover composition of the riparian zone around streams and rivers can affect stream temperature and fish community (Malcolm et al. 2004; Lorion et al. 2009; Sheldon et al. 2012). The 25 land cover classes were generalized into four categories (surface water, development, agriculture, and forested) for the whole of the watershed and six categories (river floodplains, small stream riparian habitats, wetland, development, agriculture, and forested) for the buffered stream area and the percentages of each 
generalized category were calculated. The land cover category "water" was not considered in the stream buffer analysis because it corresponded to the stream and not the riparian area surrounding it.

Dam/Impoundments, active and abandoned oil/gas wells, WVDEP National Pollutant Discharge Elimination System (NPDES) outfalls, EPA Permit Compliance System (PCS) sites, and EPA Resource Conservation and Recovery Act (RCRA) sites were summarized by total count within each watershed (WVDEP 2018a; WVDEP 2018b). RCRA sites are locations for management and disposal of hazardous and non-hazardous solid waste and are often located at individual businesses, manufacturing sites, and retail locations. The EPA's Permit Compliance System (PCS) sites track locations of discharges into rivers and other bodies of water with National Pollutant Discharge Elimination System (NPDES) permits. The NPDES permit program information can be used to map releases to surface waters of each state (WVDEP 2018b).

Total road length, road density, highway length, and natural gas pipeline length were calculated within each watershed (ESRI 2012a; ESRI 2012b). Existing oil and gas pipeline features are mapped as generalized linear features by the U.S. Energy Information Administration (U.S. EIA 2018). West Virginia 2018 surface tax parcel data were used to calculate the percentage of large corporate landowners, private land, and public land by dividing their area by the total watershed area (WV Department of Tax and Revenue 2018). The number of cities and towns were counted using TIGER/Line shapefiles from the U.S. Census Bureau (2010).

Results

Genetics 
In 2018, only 5 hybrids were identified out of the 138 collected and genotyped. In 2019, 3 hybrids were identified out of 102 genotyped. These individuals were not introduced into the $\mathrm{CCW}$ or the LBRW. There were no significant departures from HWE in the populations at each locus following sequential Bonferroni correction. At locus Eos-C2, two subpopulations showed evidence of stutter or allelic dropout, so it was only used to diagnose hybrids, then removed from the dataset and subsequent analyses. The rest of the loci $(n=12)$ were kept in the dataset.

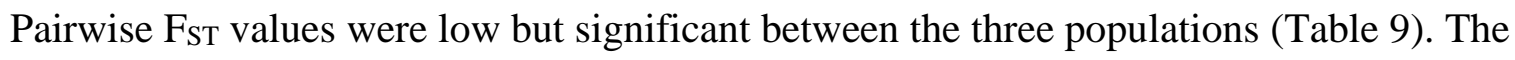
Greenbrier population had the highest allelic richness, but it was not significantly different than the allelic richness of Camp Creek or the Little Bluestone River ( $p$ > 0.05) (Table 10). Each population had comparable observed and expected heterozygosity (Table 10). No populations had significantly high within-population relatedness (Figure 8). Allelic richness was lowest in Deer Creek and highest in the Little River East Fork Greenbrier River in the Greenbrier drainage population. Knapp Creek had the lowest expected heterozygosity and the Little River East Fork Greenbrier River had the highest expected heterozygosity within the Greenbrier drainage population.

\section{Landscape}

"Dry-Mesic Oak Forests" is the highest percentage land cover class for both the CCW (38.39\%) and the LBRW (37.75\%), while Northern Hardwood Forests were the most common for the UGW. (Table 11; Figure 9). Northern Hardwood Forests and Montane Red Oak Forests were present in the CCW, but not in the LBRW. Montane Red Oak Forests were not present in the UGW. The UGW watershed contains $10.55 \%$ Red Spruce Forests which were not present in the CCW or the LBRW. All the watersheds were dominated by forest, with the UGW having the highest percentage and the LBRW having the lowest percentage of forest and the highest 
percentage of agriculture and development (Figure 10). The riparian buffer area (100m) around the streams was dominated by forest in all three watersheds. The LBRW riparian area had the highest percentage $(9.29 \%)$ of agriculture (Table 12; Figure 11).

Camp Creek State Park and Forest made up a large area $\left(15.74 \mathrm{~km}^{2}\right)$ of public land in the CCW (Figure 12). A small section of The LBRW at the mouth of the Little Bluestone River is protected as part of the Bluestone National Scenic River, but the remaining $99 \%$ of the watershed is privately owned. Contrastingly, the vast majority (80.15\%) of the UGW is publicly owned because it lies within Monongahela National Forest. None of the watersheds contain a town or city $>2,500$ people. The LBRW contains the three unincorporated communities of Nimitz, Streeter, and Jumping Branch. The CCW's only unincorporated community is Camp Creek. The UGW contains the town of Durbin with 293 people and seven other unincorporated communities. The LBRW has more roads and a density of roads compared to the CCW and the UGW (Table 13; Figure 13). Interstate 77 runs north to south in the CCW and US route 250 runs north to south in the UGW. All of the watersheds have one major state highway (CCW = SR19; $\mathrm{LBRW}=\mathrm{SR} 3$; UGW SR28).

The CCW and the UGW have more resource extraction activity than the LBRW in terms of active and abandoned oil/gas wells (Table 14; Figure 14). The CCW has a higher percentage of land owned by large corporations. An interstate Columbia Natural Gas pipeline runs through the southernmost portion of the LBRW and the northernmost portion of the CCW. There are only a few EPA permitted sites in the CCW and the LBRW and they are associated with individual landowners, apartment complexes, and businesses. Camp Creek State Park and Forest is responsible for a NPDES sewage discharge. The UGW has more EPA permitted sites and they are related to timber activities, industrial stormwater, water treatment and general sewage. 
Discussion

There are many guidelines on performing reintroductions with some accounting for genetics (George et al. 2009; Olden et al. 2010; Dunham et al. 2011). One of the major rules is do not harm the source population. There are no physical barriers (such as dams) to the $E$. variatum hybrid swarm that is quickly moving up the Greenbrier drainage (Gibson et al. 2019). While removing too many individuals could hurt the Greenbrier drainage population, without acting quickly, this population is likely to become extirpated through introgressive hybridization. It is difficult to estimate how fast action needs to be taken, but $E$. variatum expanded rapidly into the Greenbrier River drainage between 2004 and 2014 (Gibson et al. 2019). The Greenbrier drainage population in the headwaters is robust and genetically diverse. There is a low level of genetic differentiation among subpopulations in the Greenbrier drainage (Chapter 2), which reduces the chances of outbreeding depression if individuals are collected from throughout the drainage.

If managers continue to collect individuals for reintroductions and captive breeding, it would be beneficial to collect from different streams within the drainage to not deplete the subpopulations of the East Fork Greenbrier River and West Fork Greenbrier River. Repeated sampling of these rivers needs to be conducted to estimate the total population size in order to determine how many fish to take without doing unnecessary harm. The uppermost headwaters of the Greenbrier River drainage (East and West Fork Greenbrier Rivers) have the lowest levels of hybridization and it may be difficult to collect pure E. osburni in other tributaries. The Little River East Fork Greenbrier River is a tributary of the East Fork Greenbrier River and 23 individuals have been collected for translocation there so far. It is a good candidate for additional collections because it has high allelic diversity and low levels of hybridization being so far into 
the headwaters. Repeat stocking into reintroduced populations is strongly associated with reintroduction success by propagule pressure because environmental stochasticity may prevent E. osburni from spawning in a particular year (Lyon et al. 2012; Cochran-Biederman et al. 2014). Deer Creek and Knapp Creek have the lowest allelic richness amongst the subpopulations, so they may not be the best candidates. The Sitlington Creek subpopulation, with a relatively low heterozygosity, but relatively high allelic richness, is a good candidate as a source subpopulation.

For the newly reintroduced populations to sustain themselves in the long term, they need to have high genetic diversity to prevent inbreeding. If these new populations are going to become the "rescued" Greenbrier Drainage population, they should adequately capture the diversity of the source population. The reintroduced populations have significant but low differentiation from the source Greenbrier population based on F $_{\text {ST }}$ values. Individuals within these populations are not significantly related to one another. There were not significant differences in allelic richness and heterozygosity between the Greenbrier drainage population and the Camp Creek and Little Bluestone River population.

In terms of genetics, the two newly established populations capture the genetic diversity of their source population. It will be important to supplement them with more individuals whether by captive propagation or continued translocations because repeated stocking is correlated with reintroduced population persistence (Lyon et al. 2012; Cochran-Biederman et al. 2014). The exact number of individuals that need to be introduced to establish a viable population is debated and depends on the circumstances and life history of the focal species. For example, Fischer and Lindenmayer (2000) found that reintroductions were more successful if $>100$ individuals were introduced. The review contained mostly bird and mammal studies, so 
their different reproductive life history strategies may require more individuals for success than fish that can produce many more offspring. Tracy et al. (2011) developed a model framework for a threatened passerine, the mohua (Mohoua ochrocephala), and found that 60 founder individuals were sufficient to preserve allelic richness over time. Parental care is also associated with reintroduction success for freshwater fish (Cochran-Biederman et al. 2014). E. osburni are highly territorial during the spawning season, but there is not yet documentation of parental care behavior (Kelly et al. 2012; Dunn 2017).

If supplementation happens through captive breeding, genetic management is vital. Captive propagation can be fraught for numerous reasons. In addition to being expensive, individuals can suffer from reduced diversity, disease, reduced fitness, and selection or adaptation to a captive environment (Kleiman et al. 2000; Araki et al. 2007; Frankham 2008; Christie et al. 2012; Smallbone et al. 2016). Many of these problems are bypassed when using wild caught individuals for translocations because they are less likely to suffer the negative effects of artificial selection (Meffe 1986). All E. osburni collected for captive propagation will be genotyped to ensure no hybrids are present, then they will need to be propagated in a way to maximize success and minimize inbreeding. Success in propagation programs depends on the balance of having a sufficient number of individuals to introduce and time (generations) in captivity (Robert 2009). To avoid inbreeding, minimum kinship selection in the broodstock can maintain allelic diversity and produce better outcomes when compared to random mating (Sekino et al. 2004; Ortega-Villaizan et al. 2011; Willoughby et al. 2017;).

Another guideline for successful reintroductions is to reintroduce individuals into suitable habitat inside the species' native range where the original reason for decline is not present (Fischer \& Lindenmayer 2000; Cochran-Bierdman et al. 2014). Translocations and 
reintroductions inside E. osburni's native range are difficult because the primary threat is hybridization with the non-native $E$. variatum which has taken over much of $E$. osburni's historic range (Gibson et al. 2019). E. variatum is currently blocked from moving into the Gauley River population by the Summersville Dam. The Bluestone Dam blocks E. variatum from moving into the Bluestone drainage and Virginia populations. Managers chose Camp Creek and the Little Bluestone River because they possess good in-stream habitat and do not currently pose a hybridization risk. Additionally, there is evidence of historic populations in these watersheds.

The CCW and LBRW are highly forested and have low levels of agriculture and development with the LBRW having more overall. Neither new watershed is as heavily forested as the source UGW and neither contains the Northern Hardwood Forests. Forest type may be a proxy for elevation which can affect stream temperature, precipitation, and slope. The mean elevation in the UGW is higher than the mean elevation in the CCW and the LBRW (Table 13). E. osburni may be locally adapted to streams in Northern Hardwood Forests which could affect reintroduction success. The CCW and the LBRW are near the edge of the Appalachian Plateau and Valley and Ridge Region and the UGW crosses boundary zone between the Valley and Ridge Region and the Appalachian Plateau. These different geologic and landscape characteristics may be a driving factor in genetic differentiation. The Gauley River drainage population is highly differentiated compared to the Greenbrier River drainage population (Chapter 2). The Kanawha Darter (E. kanawhae; Raney 1941) is E. osburni's putative parapatric sister-species and its range begins as the where the Valley and Ridge region changes to Blue Ridge Mountain region (Dunn 2017).

The higher levels of agriculture and development are a potential threat to the reintroduced populations because even at moderate levels, agricultural land cover and impervious surfaces and 
land cover can impact fish distribution and genetics (Hudy et al. 2008; Nathan et al. 2019). The CCW has substantially more resource extraction activity, but it also contains a large area of public land in the form of Camp Creek State Park and Forest. Endangered species are protected on private land, but it is more difficult to perform monitoring and habitat modifications in these areas. Many of the oil and gas wells are in the headwaters of Camp Creek and could pose a threat to the water quality of whole watershed (Entrekin et al. 2011). The construction and drilling of wells can affect streams because forest is cut, land is cleared, and heavy equipment is brought into the area. In the CCW, most of the wells were constructed in the mid-2000s and based on permit dates there are not new wells being constructed. Overall, these new habitats capture the source habitat quality. The LBRW is potentially more difficult to monitor with such small percentage of private land. The streams may also be subject to more agricultural runoff and inputs compared to the CCW and the UGW.

Additional landscape level comparisons that include slope, air temperature, water temperature and precipitation need to be conducted to evaluate the suitability of the CCW and the LBRW to sustain E. osburni populations. Monitoring of in stream habitat variables like substrate size, flow, degree of embeddedness, and stream temperature will provide a better picture of habitat quality within the streams of these watersheds. The future of the reintroduced populations in Camp Creek and the Little Bluestone River is promising if continued stocking and genetic monitoring persist. The genetics of the new populations generally capture the genetics of the source population, but more individuals should be reintroduced to mitigate any mortality from year to year. While the landscapes of the new watersheds are mostly forested, the difference in elevation and latitude contributes to a difference in forest type between the source watershed and the effect of this on E. osburni is unknown. Characteristics like higher prevalence 
of agriculture and larger amounts of private lands may present management challenges. The biggest threat to reintroduced populations is the potential for E. variatum to establish above the Bluestone Dam, but managers are making efforts to combat this with new regulations on darters in West Virginia. Persistence of these new populations in the long-term will be determined by a comprehensive genetic monitoring and stocking program. 


\section{LITERATURE CITED}

Allan, J. D. 2004. Landscapes and riverscapes: The influence of land use on stream ecosystems. Annual Review of Ecology Evolution and Systematics. 35:257-284.

Araki, H., B. Cooper, and M. S. Blouin. 2007. Genetic effects of captive breeding cause a rapid, cumulative fitness decline in the wild. Science. 318.5847:100-103.

Armstrong, D. P., and P. J. Seddon. 2008. Directions in reintroduction biology. Trends in Ecology \& Evolution. 23.1:20-25.

Austin, J., H. Jelks, B. Tate, A. Johnson, and F. Jordan. 2011. Population genetic structure and conservation genetics of threatened Okaloosa darters (Etheostoma okaloosae). Conservation Genetics. 12:981-989.

Balian, E. V., H. Segers, C. Leveque, and K. Martens. 2008. The freshwater animal diversity assessment: An overview of the results. Hydrobiologia. 595:627-637.

Beneteau, C. L., R. P. Walter, N. E. Mandrak, and D. D. Heath. 2012. Range expansion by invasion: genetic characterization of invasion of the greenside darter (Etheostoma blennioides) at the northern edge of its distribution. Biological Invasions. 14.1:191-201.

Blanchet, S., O. Rey, R. Etienne, S. Lek, and G. Loot. 2010. Species-specific responses to landscape fragmentation: implications for management strategies. Evolutionary Applications. 3.3:291-304.

Brogdon, S.M., C.R. Tabit, and L.G. Kral. 2003. Population structure of the Tallapoosa Darter (Etheostoma tallapoosae). Southeastern Naturalist. 2:187-498.

Cessna, J. F., R. L. Racely, J. V. Kilian, D. A. Cincotta, and R. H. Hilderbrand. 2014. Rapid colonization of the Potomac River drainage by the Rainbow Darter (Etheostoma caeruleum) following introduction. Northeastern Naturalist. 21.1:1-11.

Chipps, S. R., W. B. Perry, and S. A. Perry. 1994. Patterns of microhabitat use among four species of darters in three Appalachian streams. American Midland Naturalist. 131:175180.

Christie, M. R., M. L. Marine, R. A. French, and M. S. Blouin. 2012. Genetic adaptation to captivity can occur in a single generation. Proceedings of the National Academy of Sciences of the United States of America. 109.1:238-242.

Clayton, J.L., and R. Menendez. 1996. Chemical and fishery responses to mitigative liming of an acidic stream, Dogway Fork, West Virginia. Restoration Ecology. 4.3:220-233.

Cochran-Biederman, J. L., K. E. Wyman, W. E. French, and G. L. Loppnow. 2015. Identifying correlates of success and failure of native freshwater fish reintroductions. Conservation Biology. 29.1:175-186.

Cornuet, J.M. and G., Luikart. 1997. Description and power analysis of two tests for detecting recent population bottlenecks from allele frequency data. Genetics. 144:2001-2014. 
Crandall, K. A., O. R. P. Bininda-Emonds, G. M. Mace, and R. K. Wayne. 2000. Considering evolutionary processes in conservation biology. Trends in Ecology \& Evolution. 15.7:290-295.

de Guia, A. P. O., and T. Saitoh. 2007. The gap between the concept and definitions in the Evolutionarily Significant Unit: the need to integrate neutral genetic variation and adaptive variation. Ecological Research. 22.4:604-612.

Do, C., Waples, R. S., Peel, D., Macbeth, G. M., Tillett, B. J. and J. R., Ovenden, 2014. NeEstimator V2: re-implementation of software for the estimation of contemporary effective population size (Ne) from genetic data. Molecular Ecology Resources. 14:209214.

Dudgeon, D., and coauthors. 2006. Freshwater biodiversity: importance, threats, status and conservation challenges. Biological Reviews. 81.2:163-182.

Dunham, J., K. Gallo, D. Shively, C. Allen, and B. Goehring. 2011. Assessing the feasibility of native fish reintroductions: a framework applied to threatened Bull Trout. North American Journal of Fisheries Management. 31.1:106-115.

Dunn, C. G., and P. L. Angermeier. 2016. Development of habitat suitability indices for the Candy Darter, with cross-scale validation across representative populations. Transactions of the American Fisheries Society.145.6:1266-1281.

Dunn. C. G. 2017. Habitat and imperilment of the Candy Darter Etheostoma osburni in the New River drainage, USA. Virginia Polytechnic Institute and State University. Master's thesis.

Dunn, C. G., and P. L. Angermeier. 2019. Remaining populations of an upland stream fish persist in refugia defined by habitat features at multiple scales. Biodiversity Research. 25.3:385-399.

Entrekin, S., M. Evans-White, B. Johnson, and E. Hagenbuch. 2011. Rapid expansion of natural gas development poses a threat to surface waters. Frontiers in Ecology and the Environment. 9.9:503-511.

Euclide, P. T., N. M. Flores, M. J. Wargo, C. W. Kilpatrick, and J. E. Marsden. 2018. Lack of genetic population structure of Slimy Sculpin in a large, fragmented lake. Ecology of Freshwater Fish. 27.3:699-709.

Evans, M., Y.W. Li, and Malcom J. 2020. Recovery Units under the Endangered Species Act could be used more widely. bioRxiv. doi: 10.1101/2020.03.15.991174.

Earl, D. A., and B. M. vonHoldt. 2012. STRUCTURE HARVESTER: a website and program for visualizing STRUCTURE output and implementing the Evanno method. Conservation Genetics Resources. 4.2:359-361.

Esri 2012a. StreetMap North America. US and Canada Detailed Streets. Digital map, 1:100,000 scale. Environmental Systems Research Institute, Redlands CA.

Esri 2012b. StreetMap North America. US and Canada Highways. Digital map, 1:100,000 scale. Environmental Systems Research Institute, Redlands CA. 
Esri 2017. ArcGIS Desktop 10.6. Environmental Systems Research Institute, Redlands CA.

Evanno, G., S. Regnaut, and J. Goudet. 2005. Detecting the number of clusters of individuals using the software STRUCTURE: a simulation study. Molecular Ecology. 14.8:26112620 .

Excoffier L., G. Laval, and S. Schneider 2005. Arlequin (version 3.0): an integrated software package for population genetics data analysis. Evolutionary Bioinformatics. 1:147-150.

Fischer, J., and D. B. Lindenmayer. 2000. An assessment of the published results of animal relocations. Biological Conservation. 96.1:1-11.

Fish and Wildlife Service. 2018. Endangered and threatened wildlife and plants; endangered species status for the Candy Darter. 83 Fed. Reg. 225. Federal Register: The Daily Journal of the United States. Web.

Frankham, R. 2008. Genetic adaptation to captivity in species conservation programs. Molecular Ecology. 17.1:325-333.

Frankham, R., C. J. A. Bradshaw, and B. W. Brook. 2014a. 50/500 rules need upward revision to 100/1000-Response to Franklin et al. Biological Conservation. 176:286.

Frankham, R., C. J. A. Bradshaw, and B. W. Brook. 2014b. Genetics in conservation management: Revised recommendations for the 50/500 rules, Red List criteria and population viability analyses. Biological Conservation. 170:56-63.

Franklin, I.R. 1980. Evolutionary change in small populations. Conservation Biology: an Evolutionary-Ecological Perspective (Soule', M.E. and Wilcox, B.A., eds). Sinauer Associates. pp.135-150.

Franklin, I. R., F. W. Allendorf, and I. G. Jamieson. 2014. The 50/500 rule is still valid - Reply to Frankham et al. Biological Conservation. 176:284-285.

Fraser, D. J., and L. Bernatchez. 2001a. Adaptive evolutionary conservation: towards a unified concept for defining conservation units. Molecular Ecology. 10.12:2741-2752.

Funk, W. C., J. K. McKay, P. A. Hohenlohe, and F. W. Allendorf. 2012. Harnessing genomics for delineating conservation units. Trends in Ecology \& Evolution. 27.9:489-496.

George, A. L., and coauthors. 2009. Guidelines for propagation and translocation for freshwater fish conservation. Fisheries. 34.11:529-545.

Gibson, I. 2017. Conservation concerns for the Candy Darter (Etheostoma osburni) with implications related to hybridization. West Virginia University, Morgantown WV. Master's thesis.

Gibson, I., A.B. Welsh, S.A.Welsh, and D.A. Cincotta. 2019. Genetic swamping and species collapse: tracking introgression between the native Candy Darter and introduced Variegate Darter. Conservation Genetics. 20.2:287-298.

Goudet, J. 2002. FSTAT version 2.9. 3.2, a program to estimate and test gene diversities and fixation indices. Institute of Ecology, Lausanne, Switzerland. http://www2.unil.ch/popgen/softwares/fstat htm 
Gouskov, A., and C. Vorburger. 2016. River fragmentation and fish population structure: a comparison of three Swiss midland rivers. Freshwater Science. 35.2:689-700.

Hack, J.T. 1973. Drainage adjustment in the Appalachians. Fluvial geomorphology. State University of New York, Binghamtom, New York. Pgs. 51-69

Holcomb, K. M., P. Schueller, H. L. Jelks, J. R. Knight, and M. S. Allen. 2020. Use of strong habitat-abundance relationships in assessing population status of cryptic fishes: an example using the Harlequin Darter. Transactions of the American Fisheries Society. 149.3:320-334.

Holt, D. E., H. L. Jelks, and F. Jordan. 2013. Movement and longevity of imperiled Okaloosa Darters (Etheostoma okaloosae). Copeia. 4:653-659.

Horreo, J. L., and coauthors. 2011. Impact of habitat fragmentation on the genetics of populations in dendritic landscapes. Freshwater Biology. 56.12:2567-2579.

Hubbs, C. L., and M. B. Trautman. 1932. Poecilichthys osburni, a new darter from the upper Kanawha River system in Virginia and West Virginia. Ohio Journal of Science. 32:31-38.

Hubbs, C. L., and J. D. Black. 1940. Percid fishes related to Poecilichthys variatus, with descriptions of three new forms. Occasional Papers Museum of Zoology, University of Michigan. Number 416.

Hudy, M., T. M. Thieling, N. Gillespie, and E. P. Smith. 2008. Distribution, status, and land use characteristics of subwatersheds within the native range of Brook Trout in the Eastern United States. North American Journal of Fisheries Management. 28.4:1069-1085.

Hulce, D., X. Li, T. Snyder-Leiby, and C.S. Johathan Liu. 2011. GeneMarker® genotyping software: tools to increase the statistical power of DNA fragment analysis. Journal of Biomolecular Techniques. 22.Suppl:S35-S36.

IUCN (World Conservation Union). 1998. Guidelines for re-introductions. IUCN/SSC Reintroduction Specialist Group, IUCN, Gland, Switzerland, and Cambridge, United Kingdom.

Jenkins, R. E., and N. M. Burkhead. 1994. Freshwater fishes of Virginia. American Fisheries Society, Bethesda, Maryland.

Keck, B. P., and T. J. Near. 2009. Patterns of natural hybridization in darters (Percidae: Etheostomatinae). Copeia. 4:758-773.

Kelly, N. B., T.J. Near, and S. H. Alonzo. 2012. Diversification of egg-deposition behaviours and the evolution of male parental care in darters (Teleostei: Percidae: Etheostomatinae). Journal of Evolutionary Biology. 5:836-846.

Kirtland, J. P. 1840. Descriptions of four new species of fishes. Boston Journal of Natural History. 3:273-277.

Kleiman, D. G., and coauthors. 2000. Improving the evaluation of conservation programs. Conservation Biology. 14.2:356-365. 
Lorion, C. M., and B. P. Kennedy. 2009. Riparian forest buffers mitigate the effects of deforestation on fish assemblages in tropical headwater streams. Ecological Applications. 19.2:468-479.

Lyon, J. P., and coauthors. 2012. Reintroduction success of threatened Australian Trout Cod (Maccullochella macquariensis) based on growth and reproduction. Marine and Freshwater Research. 63.7:598-605.

Malcolm, I. A., D. M. Hannah, M. J. Donaghy, C. Soulsby, and A. F. Youngson. 2004. The influence of riparian woodland on the spatial and temporal variability of stream water temperatures in an upland salmon stream. Hydrology and Earth System Sciences. 8.3:449-459.

Messinger, T. and C. Hughes. 2000. Environmental setting and its relations to water quality in the Kanawha River basin (Report No. 00-4020). Reston, Virginia: U.S. Geological Survey, Water Resources Investigations.

McBaine, K. and E. Hallerman. 2020. Demographic status and population genetic differentiation of Candy Darter populations in Virginia. Final Report submitted to: Virginia Department of Game and Inland Fisheries, South Main Street, Blacksburg, VA.

Meffe, G. K. 1986. Conservation genetics and the management of endangered fishes. Fisheries. 11.1:14-23.

Montalvo, A. M., and coauthors. 1997. Restoration biology: A population biology perspective. Restoration Ecology. 5.4:277-290.

Moritz, C. 1994. Defining "evolutionary significant units" for conservation. Trends in Ecology and Evolution. 9:373-375.

Moritz, C. 1999. Conservation units and translocations: strategies for conserving evolutionary processes. Hereditas. 130.3:217-228.

Nathan, L. R., A. B. Welsh, and J. C. Vokoun. 2019. Watershed-level brook trout genetic structuring: Evaluation and application of riverscape genetics models. Freshwater Biology. 64.3:405-420.

National Center for Biotechnology Information (NCBI)[Internet]. Bethesda (MD): National Library of Medicine (US), National Center for Biotechnology Information. URL: https://www.ncbi.nlm.nih.gov/nucleotide/ Retrieved: 10/23/2018.

National Marine Fisheries Service. 2018. Interim endangered and threatened species recovery planning guidance (section 2.1 only).

Natural Resource Analysis Center, 2020. WV Land use land cover (NAIP 2016). Digital spatial dataset. Natural Resource Analysis Center, West Virginia University, Morgantown WV. URL: http://wvgis.wvu.edu/data/dataset.php?ID=489. Retrieved 2/12/2020.

Nei, M., F. Tajima, and Y. Tateno. 1983. Accuracy of estimated phylogenetic trees from molecular data. Journal of Molecular Evolution. 19:153-170. 
Olden, J. D., M. J. Kennard, J. J. Lawler, and N. L. Poff. 2011. Challenges and opportunities in implementing managed relocation for conservation of freshwater species. Conservation Biology. 25.1:40-47.

Olsen, J.B., A. P. Kinziger, J. K. Wenburg, C. J. Lewis, C. T. Phillips, and K. G. Ostrand. 2016. Genetic diversity and divergence in the fountain darter (Etheostoma fonticola): implications for conservation of an endangered species. Conservation Genetics. 17:13931404.

Ortega-Villaizan, M. D., D. Noguchi, and N. Taniguchi. 2011. Minimization of genetic diversity loss of endangered fish species captive broodstocks by means of minimal kinship selective crossbreeding. Aquaculture. 318.1-2:239-243.

Palsbøll, P.J., M. Bérubé, and F.W. Allendorf. 2007. Identification of management units using population genetic data. Trends in Ecology and Evolution. 22.1:11-16.

Peakall, R., and P.E., Smouse. 2012. GenAlEx 6.5: genetic analysis in Excel. Population genetic software for teaching and research-an update. Bioinformatics. 28:2537-2539.

Pritchard, J. K., M. Stephens, and P. Donnelly. 2000. Inference of population structure using multilocus genotype data. Genetics. 155:945-959.

Queller, D.C. and K.F. Goodnight. 1989. Estimating relatedness using genetic markers. Evolution. 43.2:258-275.

Raney, E. C. 1941. Poecilichthys kanawhae, a new darter from the upper New River system in North Carolina and Virginia. Occasional Papers of the Museum of Zoology, University of Michigan. Number 434.

Raymond, M., and F. Rousset. 1995. GENEPOP (version 1.2): population genetics software for exact tests and ecumenicism. Journal of Heredity. 86:248-249.

Reed, D.H. and R. Frankham. 2003. Correlation between fitness and genetic diversity. Conservation Biology. 17:230-237.

Rhymer, J. M., and D. Simberloff. 1996. Extinction by hybridization and introgression. Annual Review of Ecology and Systematics. 27:83-109.

Rice, W. R. 1989. Analyzing tables of statistical tests. Evolution. 43:223-225.

Rosenfeld, J. 2003. Assessing the habitat requirements of stream fishes: An overview and evaluation of different approaches. Transactions of the American Fisheries Society. 132.5:953-968.

Roth, N. E., J. D. Allan, and D. L. Erickson. 1996. Landscape influences on stream biotic integrity assessed at multiple spatial scales. Landscape Ecology. 11.3:141-156.

Ruzich, J., K. Turnquist, N. Nye, D. Rowe, and W. A. Larson. 2019. Isolation by a hydroelectric dam induces minimal impacts on genetic diversity and population structure in six fish species. Conservation Genetics. 20.6:1421-1436. 
Schoolcraft, A. E., D. C. Tarter, and D. A. Cincotta. 2007. Food habits of the Candy Darter, Etheostoma osburni (Hubbs and Trautman), in the Cherry River, West Virginia. Proceedings of the West Virginia Academy of Science. 79:2.

Schwartz, M. K., G. Luikart, and R. S. Waples. 2007. Genetic monitoring as a promising tool for conservation and management. Trends in Ecology \& Evolution. 22.1:25-33.

Sekino, M., T. Sugaya, M. Hara, and N. Taniguchi. 2004. Relatedness inferred from microsatellite genotypes as a tool for broodstock management of Japanese flounder Paralichthys olivaceus. Aquaculture. 233.1-4:163-172.

Sheldon, F., and coauthors. 2012. Identifying the spatial scale of land use that most strongly influences overall river ecosystem health score. Ecological Applications. 22.8:2188-2203.

Smallbone, W., C. Van Oosterhout, and J. Cable. 2016. The effects of inbreeding on disease susceptibility: Gyrodactylus turnbulli infection of guppies, Poecilia reticulata. Experimental Parasitology. 167:32-37.

Stauffer, J. R., J. M. Boltz, and L. R. White. 1995. Fishes of West Virginia. The Proceedings of the Academy of Natural Sciences of Philadelphia. Philadelphia, Pennsylvania.

Strager, J.M. 2019. GIS-based landscape level threat assessment for the Candy Darter (Etheostoma osburni). Natural Resources Analysis Center, West Virginia University, Morgantown, WV. Final Report submitted to: U.S. Geological Survey and U.S. Fish and Wildlife Service.

Switzer, J. F., S. A. Welsh, and T. L. King. 2007. A molecular genetic investigation of hybridization between Etheostoma osburni and Etheostoma variatum in the New River drainage, West Virginia. Final Report submitted to: West Virginia Division of Natural Resources, Ward Road, Elkins, WV.

Switzer, J. F., S. A. Welsh, and T. L. King. 2008. Microsatellite DNA primers for the Candy Darter, Etheostoma osburni and Variegate Darter, Etheostoma variatum, and crossspecies amplification in other darters (Percidae). Molecular Ecology Resources. 8.2: 335338.

Takezaki, N., M. Nei, and K. Tamura. 2010. POPTREE2: Software for constructing population trees from allele frequency data and computing other population statistics with windows interface. Molecular Biology and Evolution. 27:747-752.

Todesco, M., and coauthors. 2016. Hybridization and extinction. Evolutionary Applications. 9.7:892-908.

Tracy, L. N., G. P. Wallis, M. G. Efford, and I. G. Jamieson. 2011. Preserving genetic diversity in threatened species reintroductions: how many individuals should be released? Animal Conservation. 14.4:439-446.

U.S. Census Bureau 2010. TIGER/Line Shapefiles: Census blocks with population and housing counts. U.S. Census Bureau, Washington, DC. URL: https://www.census.gov/geographies/mapping-files/timeseries/geo/tiger-linefile.2010.html. Retrieved: 2/12/2020. 
U.S. Department of the Interior. 2018. Endangered and threatened wildlife and plants; endangered species status for the Candy Darter. Federal Register. 83.225: 58747-58754.

U.S. Department of the Interior and U.S. Department of Commerce.1996. Policy regarding the recognition of distinct vertebrate population segments under the Endangered Species Act. Federal Register 61:4722-4725.

U.S. Energy Information Administration. 2018. Natural gas interstate and intrastate pipelines. Digital dataset. U.S. Energy Information Administration, Washington, DC. URL: https://www.eia.gov/maps/layer_info-m.php. Retrieved: 2/12/2020.

U.S. Fish and Wildlife Service. 2016. USFWS Species Status Assessment framework: an integrated analytical framework for conservation. Version 3.4 dated August 2016.

U.S. Geological Survey. 2016. USGS National Elevation Dataset (NED) 1 arc-second Downloadable Data Collection from The National Map 3D Elevation Program (3DEP) National Geospatial Data Asset (NGDA) National Elevation Data Set (NED): U.S. Geological Survey, Reston VA.

U.S. Geological Survey. 2019. NHDPlus High Resolution. U.S. Geological Survey, Reston VA. URL: https://www.usgs.gov/core-science-systems/ngp/national-hydrography/nhdplushigh-resolution, Retrieved 2/12/2020.

Van Oosterhout, C., W. F. Hutchinson, D. P. M. Wills, and P. Shipley. 2003. Micro-Checker, version 2.2. 3. Department of Biological Sciences and Department of Computer Science, University of Hull, Hull, UK.

Waples, R.S. 1991. Pacific Salmon, Oncorhynchus spp. \& the definition of 'species' under the endangered species act. Marine Fisheries Reviews. 53:11-22.

Weir, B.S., and C.C. Cockerham. 1984. Estimating F-statistics for the analysis of population structure. Evolution. 38:1358-1370.

Weeks, A. R., and coauthors. 2011. Assessing the benefits and risks of translocations in changing environments: a genetic perspective. Evolutionary Applications. 4.6:709-725.

West Virginia Division of Natural Resources. 2020. West Virginia fishing regulation summary 2020. West Virginia Division of Natural Resources, $4^{\text {th }}$ Avenue, South Charleston, WV. URL: http://www.wvdnr.gov/fishing/Regs20/2020_fishingRegs.pdf pgs:10-11.

Weston, M. R., and R. L. Johnson. 2008. Visible implant elastomer as a tool for marking etheostomine darters (Actinopterygii : percidae). Southeastern Naturalist. 7.1:159-164.

Willoughby, J. R., J. A. Ivy, R. C. Lacy, J. M. Doyle, and J. A. DeWoody. 2017. Inbreeding and selection shape genomic diversity in captive populations: Implications for the conservation of endangered species. Plos One. 12.4.

WVDEP 2018a. WV Department of Environmental Protection Office of Oil and Gas oil and gas wells. WV Department of Environmental Protection, Technical Applications and GIS Unit (TAGIS), Charleston WV. URL: https://tagis.dep.wV.gov/home/downloads Retrieved 2/12/2020 
WVDEP 2018b. Water Resources NPDES Outlets (shapefile). Geospatial dataset dated 12/14/2018. West Virginia Department of Environmental Protection, Charleston, WV. URL: http://tagis.dep.wv.gov/home/Downloads. Retrieved 2/12/2020.

WVDEP. 2019b. Integrated water quality monitoring and assessment report, including impaired streams. West Virginia Department of Environmental Protection, Charleston WV. 2016 GIS shapefile. URL: https://dep.wv.gov/wwe/watershed/ir/pages/303d_305b.aspx. Retrieved 2/12/2020.

WV Department of Tax and Revenue. 2018 GIS parcels (statewide). Surface and mineral parcels - Digital spatial dataset. WV State Department of Tax and Revenue, Charleston WV and WV Geographic Information Systems Technical Center, Morgantown WV. URL: http://wvgis.wvu.edu/data/dataset.php?ID=371. Retrieved 6/22/2020. 


\section{TABLES}

Table 1. Subpopulations represented in each sample used in STRUCTURE analysis, construction of a neighbor joining tree, and for pairwise comparison of $\mathrm{F}_{\mathrm{ST}}$. List of E. osburni collection sites enumerated to correspond with the map of the study area. The total number of pure E. osburni identified at each site is provided. The subpopulation names are abbreviated versions of the collection site names.

\begin{tabular}{llcllc}
\hline & Sub-population & $\mathbf{n}_{\text {sample }}$ & Drainage & Collection sites & $\mathbf{n}_{\text {site }}$ \\
\hline 1. & L.R.E.F Greenbrier R. & 73 & Greenbrier & $\begin{array}{l}\text { 1. Little River East Fork Greenbrier } \\
\text { River }\end{array}$ & 73 \\
\hline 2. & E. F. Greenbrier R. & 118 & Greenbrier & 2. East Fork Greenbrier River & 118 \\
\hline 3. & W. F. Greenbrier R. & 72 & Greenbrier & 3. West Fork Greenbrier River & 72 \\
\hline 4. & Sitlington Cr. & 28 & Greenbrier & $\begin{array}{l}\text { 4. Sitlington Creek } \\
\text { 5. Sitlington Creek }\end{array}$ & 23 \\
\hline 5. & Knapp Cr. & \multirow{2}{*}{15} & Greenbrier & 6. Knapp Creek & 7. Knapp Creek \\
\hline 6. & Deer Cr. & 8 & Greenbrier & 8. Deer Creek & 7 \\
\hline 7. & Lower Gauley R. & 17 & Gauley & 9. Gauley River & 8 \\
\hline & & & & 10. Gauley River & 8 \\
\hline 8. & Upper Gauley R. & 33 & Gauley & 11. Gauley River & 17 \\
\hline & & & & 12. Gauley River & 11 \\
\hline 9. & Cherry R. & 32 & Gauley & 14. Cherry River & 7 \\
\hline 10. & N. F. Cherry R. & 16 & Gauley & 15. North Fork Cherry River & 2 \\
\hline 11. & S. F. Cherry R. & 16 & Gauley & 16. South Fork Cherry River & 13 \\
\hline 12. & Laurel Cr. & 17 & Gauley & 17. Laurel Creek & 16 \\
\hline 13. & Cranberry R. & 19 & Gauley & 18. Cranberry River & 16 \\
\hline 14. & Williams R. & 20 & Gauley & 19. Williams River & 17 \\
\hline & TOTAL & $\mathbf{4 8 4}$ & & & 19 \\
\hline & & & & & 20 \\
\hline
\end{tabular}


Table 2. Pairwise $F_{\text {ST }}$ values between the subpopulations in the Greenbrier and Gauley River drainages. All estimates were statistically significant after sequential Bonferroni correction for multiple comparisons $(\mathrm{p}<0.0001)$.

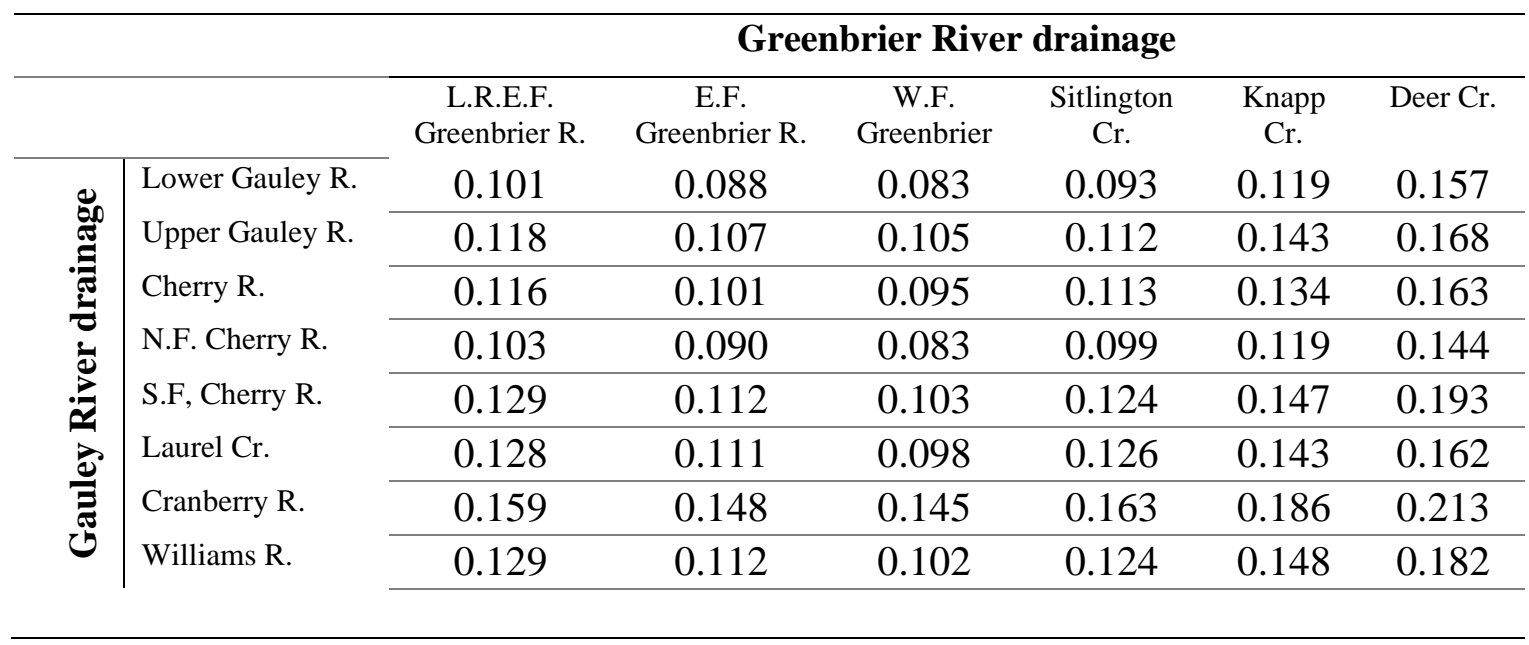


Table 3. Pairwise $F_{\text {ST }}$ values between subpopulations within the Greenbrier River drainage. Estimates in bold were statistically significant after sequential Bonferroni correction for multiple comparisons $(\mathrm{p}<0.0001)$.

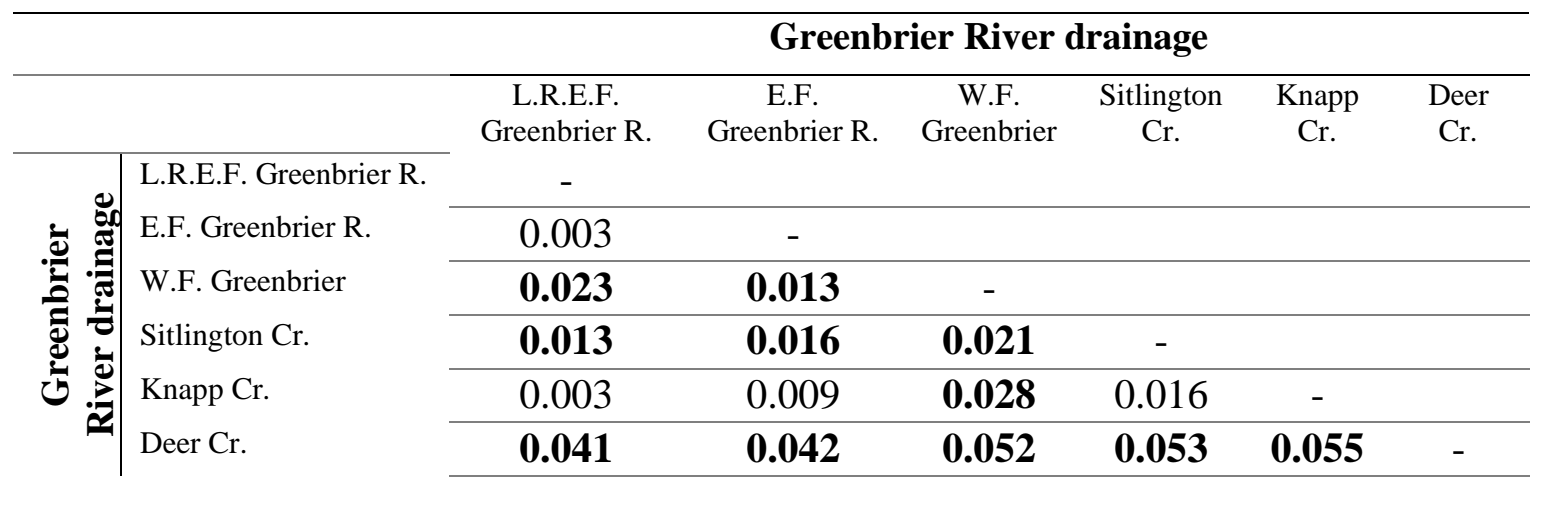




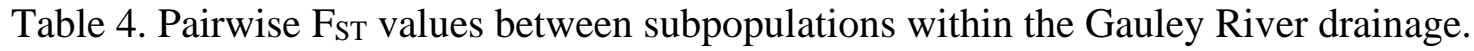

Estimates in bold were statistically significant after sequential Bonferroni correction for multiple comparisons $(\mathrm{p}<0.0001)$.

\begin{tabular}{|c|c|c|c|c|c|c|c|c|c|}
\hline \multirow{9}{*}{ 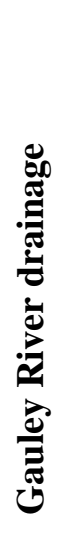 } & & \multicolumn{8}{|c|}{ Gauley River drainage } \\
\hline & Lower Gauley R. & $\begin{array}{c}\text { Lower } \\
\text { Gauley R. } \\
\text { - }\end{array}$ & $\begin{array}{c}\text { Upper } \\
\text { Gauley R. }\end{array}$ & $\begin{array}{c}\text { Cherry } \\
\text { R. }\end{array}$ & $\begin{array}{c}\text { N.F. } \\
\text { Cherry R. }\end{array}$ & $\begin{array}{c}\text { S.F. } \\
\text { Cherry R. }\end{array}$ & $\begin{array}{c}\text { Laurel } \\
\text { Cr. }\end{array}$ & $\begin{array}{c}\text { Cranberry } \\
\text { R. }\end{array}$ & $\begin{array}{l}\text { Williams } \\
\text { R. }\end{array}$ \\
\hline & Upper Gauley R. & 0.009 & - & & & & & & \\
\hline & Cherry R. & 0.013 & 0.037 & - & & & & & \\
\hline & N.F. Cherry R. & 0.002 & 0.008 & 0.004 & - & & & & \\
\hline & S.F. Cherry R. & 0.006 & 0.040 & 0.005 & 0.008 & - & & & \\
\hline & Laurel Cr. & 0.039 & 0.059 & 0.019 & 0.012 & 0.023 & - & & \\
\hline & Cranberry R. & 0.064 & 0.072 & 0.044 & 0.042 & 0.063 & 0.066 & - & \\
\hline & Williams R. & 0.007 & 0.001 & 0.031 & 0.009 & 0.029 & 0.040 & 0.062 & - \\
\hline
\end{tabular}


Table 5. Measures of diversity in both populations. Effective population size $\left(\mathrm{N}_{\mathrm{e}}\right)$ was calculated using the Linkage Disequilibrium method in NeEstimator with Jackknife confidence intervals (Do et al. 2014). Allelic richness, observed heterozygosity ( $\mathrm{H}_{\mathrm{O}}$ ), and expected heterozygosity $\left(\mathrm{H}_{\mathrm{E}}\right)$ were calculated using FSTAT (Goudet 1995).

\begin{tabular}{lccc}
\hline & Greenbrier River drainage & Gauley River Drainage & \\
\hline $\mathbf{n}$ & 336 & 172 & \\
$\mathbf{N}_{\mathbf{e}}$ & 1,299 & 388 & \\
& $(386-4,145)$ & $(150-434)$ & $\boldsymbol{p}$ value \\
\hline Relatedness & & & 0.5200 \\
\hline Allelic Richness & 0.029 & 0.057 & $\mathbf{0 . 0 0 0 1}$ \\
\hline $\mathbf{H}_{\mathbf{O}}$ & 5.459 & 4.612 & $\mathbf{0 . 0 0 3 3}$ \\
\hline $\mathbf{H}_{\mathbf{E}}$ & 0.668 & 0.599 & $\mathbf{0 . 0 0 0 4}$ \\
\hline
\end{tabular}


Table 6. Summary of E. osburni stocking events into Camp Creek and the Little Bluestone River from 2018 and 2019.

\begin{tabular}{llc}
\hline Date & Stream & N \\
\hline $\mathbf{1 2 / 4 / 2 0 1 8}$ & Mouth of Mash Fork & 40 \\
$\mathbf{1 2 / 4 / 2 0 1 8}$ & Camp Creek & 42 \\
$\mathbf{6 / 6 / 2 0 1 9}$ & Camp Creek & 18 \\
$\mathbf{6 / 6 / 2 0 1 9}$ & Camp Creek & 18 \\
$\mathbf{1 0 / 1 7 / 2 0 1 9}$ & Little Bluestone River & 84 \\
$\mathbf{1 0 / 2 4 / 2 0 1 9}$ & Camp Creek & 10 \\
\hline & Camp Creek Total $=$ & $\mathbf{1 2 8}$ \\
& Little Bluestone Total $=$ & $\mathbf{8 4}$ \\
& Total $=$ & $\mathbf{2 1 2}$ \\
\hline
\end{tabular}


Table 7. Summary of E. osburni collections for reintroduction with the number of hybrids found at each site.

\begin{tabular}{|c|c|c|c|c|}
\hline Collection Date & Stream & $\begin{array}{c}n \\
\text { total }\end{array}$ & $\stackrel{\mathbf{n}}{\text { E. osburni }}$ & $\begin{array}{c}n \\
\text { hybrids }\end{array}$ \\
\hline \multirow{2}{*}{$10 / 23 / 2018$} & Little River East Fork Greenbrier River & 23 & 22 & 1 \\
\hline & West Fork Greenbrier River & 43 & 40 & 3 \\
\hline $10 / 24 / 2018$ & East Fork Greenbrier River & 27 & 27 & 0 \\
\hline \multirow{2}{*}{$10 / 30 / 2018$} & East Fork Greenbrier River & 17 & 16 & 1 \\
\hline & West Fork Greenbrier River & 28 & 28 & 0 \\
\hline $10 / 08 / 2019$ & East Fork Greenbrier River & 102 & 99 & 3 \\
\hline
\end{tabular}


Table 8. Measures of genetic diversity in all subpopulations of the Greenbrier River population with the total number of individuals in each subpopulation. Allelic richness, observed

heterozygosity $\left(\mathrm{H}_{\mathrm{O}}\right)$, and expected heterozygosity $\left(\mathrm{H}_{\mathrm{E}}\right)$ were calculated using GenAlEx (Peakall and Smouse 2012).

\begin{tabular}{lcccc}
\hline & n & Allelic Richness & Ho & HE \\
\hline L.R.E.F. Greenbrier R. & 29 & 5.809 & 0.716 & 0.727 \\
E.F. Greenbrier R. & 5 & 5.413 & 0.705 & 0.723 \\
W.F. Greenbrier R. & 7 & 5.075 & 0.694 & 0.720 \\
Sitlington Cr. & 28 & 5.288 & 0.717 & 0.715 \\
Knapp Cr. & 15 & 4.628 & 0.715 & 0.701 \\
Deer Cr. & 8 & 3.789 & 0.740 & 0.711 \\
\hline
\end{tabular}


Table 9. Pairwise $\mathrm{F}_{\mathrm{ST}}$ values between the Greenbrier River drainage population and reintroduced Camp Creek and Little Bluestone River populations. All estimates were statistically significant with an adjusted nominal level (5\%) for multiple comparisons ( $\mathrm{p}<0.01667)$.

\begin{tabular}{lll}
\hline & Camp Creek & Little Bluestone River \\
\hline Little Bluestone River & 0.0045 & - \\
Greenbrier population & 0.0041 & 0.0034 \\
\hline
\end{tabular}


Table 10. Measures of genetic diversity in all populations. Allelic richness, observed heterozygosity $\left(\mathrm{H}_{\mathrm{O}}\right)$, and expected heterozygosity $\left(\mathrm{H}_{\mathrm{E}}\right)$ were calculated using GenAlEx (Peakall and Smouse 2012).

\begin{tabular}{lccc}
\hline & Allelic Richness & Ho & HE \\
\hline Camp Creek & 5.53 & 0.70 & 0.73 \\
Little Bluestone & 5.42 & 0.71 & 0.72 \\
Greenbrier & 5.80 & 0.71 & 0.72 \\
\hline
\end{tabular}


Table 11. Land cover composition (\%) for each watershed. Classes were created by NRAC statewide spectral classification for West Virginia using geographic object-based image analysis (GEOBIA), random forest (RF) machine learning, and National Agricultural Imagery Program (NAIP) orthophotography for mapping general land cover across the entire state. The percentage of each generalized category is visualized in Figure 10.

\begin{tabular}{llccc}
\hline & $\begin{array}{l}\text { Generalized } \\
\text { Category }\end{array}$ & CCW & LBRW & UGW \\
\hline Water & Surface Water & $0.11 \%$ & $0.33 \%$ & $0.23 \%$ \\
River Floodplains & Surface Water & $0.03 \%$ & $0.01 \%$ & $0.16 \%$ \\
Small Stream Riparian & Surface Water & $3.21 \%$ & $2.82 \%$ & $0.51 \%$ \\
Habitats & Surface Water & $0.07 \%$ & $0.04 \%$ & $0.41 \%$ \\
Wetlands PEM & Surface Water & $0.11 \%$ & $0.05 \%$ & $0.30 \%$ \\
\hline Roads & Development & $0.90 \%$ & $1.18 \%$ & $0.85 \%$ \\
Impervious & Development & $0.18 \%$ & $0.29 \%$ & $0.12 \%$ \\
Mixed Development & Development & $0.35 \%$ & $1.06 \%$ & $0.31 \%$ \\
Barren & Development & $0.65 \%$ & $0.70 \%$ & $0.19 \%$ \\
\hline Other Forest & Forested & $13.27 \%$ & $11.61 \%$ & $5.90 \%$ \\
Red Spruce Forest & Forested & $0.00 \%$ & $0.00 \%$ & $10.55 \%$ \\
Northern Hardwood Forests & Forested & $0.37 \%$ & $0.00 \%$ & $63.16 \%$ \\
Mixed Mesophytic Forests & Forested & $7.22 \%$ & $5.54 \%$ & $7.28 \%$ \\
Dry-Mesic Oak Forests & Forested & $38.39 \%$ & $37.75 \%$ & $2.16 \%$ \\
Dry Oak ( Pine) Forests & Forested & $28.01 \%$ & $24.33 \%$ & $4.70 \%$ \\
Pine Oak Rock Woodlands & Forested & $0.76 \%$ & $0.66 \%$ & $0.30 \%$ \\
Montane Red Oak Forests & Forested & $1.42 \%$ & $0.00 \%$ & $0.00 \%$ \\
\hline Low Vegetation & Agriculture & $1.57 \%$ & $2.98 \%$ & $2.03 \%$ \\
Hay/Pasture & Agriculture & $1.52 \%$ & $3.41 \%$ & $0.11 \%$ \\
Cultivated Crops & Agriculture & $1.84 \%$ & $7.24 \%$ & $0.73 \%$ \\
\hline
\end{tabular}


Table 12. Percentage of each land cover class in the $100 \mathrm{~m}$ buffer around all streams in each watershed. The land cover classes that comprise Forested, Development, and Agriculture can be found in Table 11. Water was excluded because it represented the mainstem of the stream and not the riparian area.

\begin{tabular}{lccc}
\hline & $\begin{array}{c}\text { CCW } \\
\text { Riparian Buffer }\end{array}$ & $\begin{array}{c}\text { LBRW } \\
\text { Riparian Buffer }\end{array}$ & $\begin{array}{c}\text { UGW Riparian } \\
\text { Buffer }\end{array}$ \\
\hline \% River Floodplains & 0.09 & 0.02 & 0.61 \\
\% Small Stream Riparian Habitats & 9.72 & 8.61 & 2.07 \\
\% Wetland & 0.53 & 0.22 & 2.73 \\
\hline \% Forested & 83.88 & 78.49 & 89.02 \\
\hline \% Development & 2.32 & 3.37 & 2.61 \\
\% Agriculture & 3.46 & 9.29 & 2.95 \\
\hline
\end{tabular}


Table 13. Watershed area and elevation with a comparison of watershed characteristics related to development between the CCW, the LBRW, and the UGW.

\begin{tabular}{lccc}
\hline & Camp Creek & Little Bluestone & Upper Greenbrier \\
\hline Watershed Area $\left(\mathbf{k m}^{\mathbf{2}}\right)$ & 103.60 & 90.32 & 344.50 \\
Elevation $(\mathbf{m})$ & 800.5 & 744.4 & 1057.5 \\
Road length $(\mathbf{k m})$ & 105.34 & 142.47 & 350.96 \\
Road Density $\left(\mathbf{k m} / \mathbf{k m}^{\mathbf{2}}\right)$ & 1.02 & 1.58 & 1.02 \\
Highway length $(\mathbf{k m})$ & 36.88 & 6.56 & 41.43 \\
\% Large Corporate Landowners & 15.85 & 4.87 & 4.49 \\
\% Private Land & 84.81 & 100.00 & 19.85 \\
\% Public Land & 15.19 & 1.00 & 80.15 \\
\hline
\end{tabular}


Table 14. Comparison of watershed characteristics related to resource extraction and potential impacts to water quality between the CCW, the LBRW, and the UGW.

\begin{tabular}{lccc}
\hline & Camp Creek & Little Bluestone & Upper Greenbrier \\
\hline Active Oil/Gas Wells (\#) & 85 & 0 & 23 \\
Abandoned Oil/Gas Wells (\#) & 24 & 0 & 15 \\
Natural Gas Pipeline length (km) & 5.39 & 3.55 & 0.00 \\
Dams/Impoundments (\#) & 1 & 1 & 2 \\
WVDEP NPDES outfalls (\#) & 1 & 12 & 17 \\
EPA PCS Sites (\#) & 6 & 9 & 22 \\
EPA RCRA Active Sites (\#) & 1 & 0 & 1 \\
\hline
\end{tabular}




\section{FIGURES}

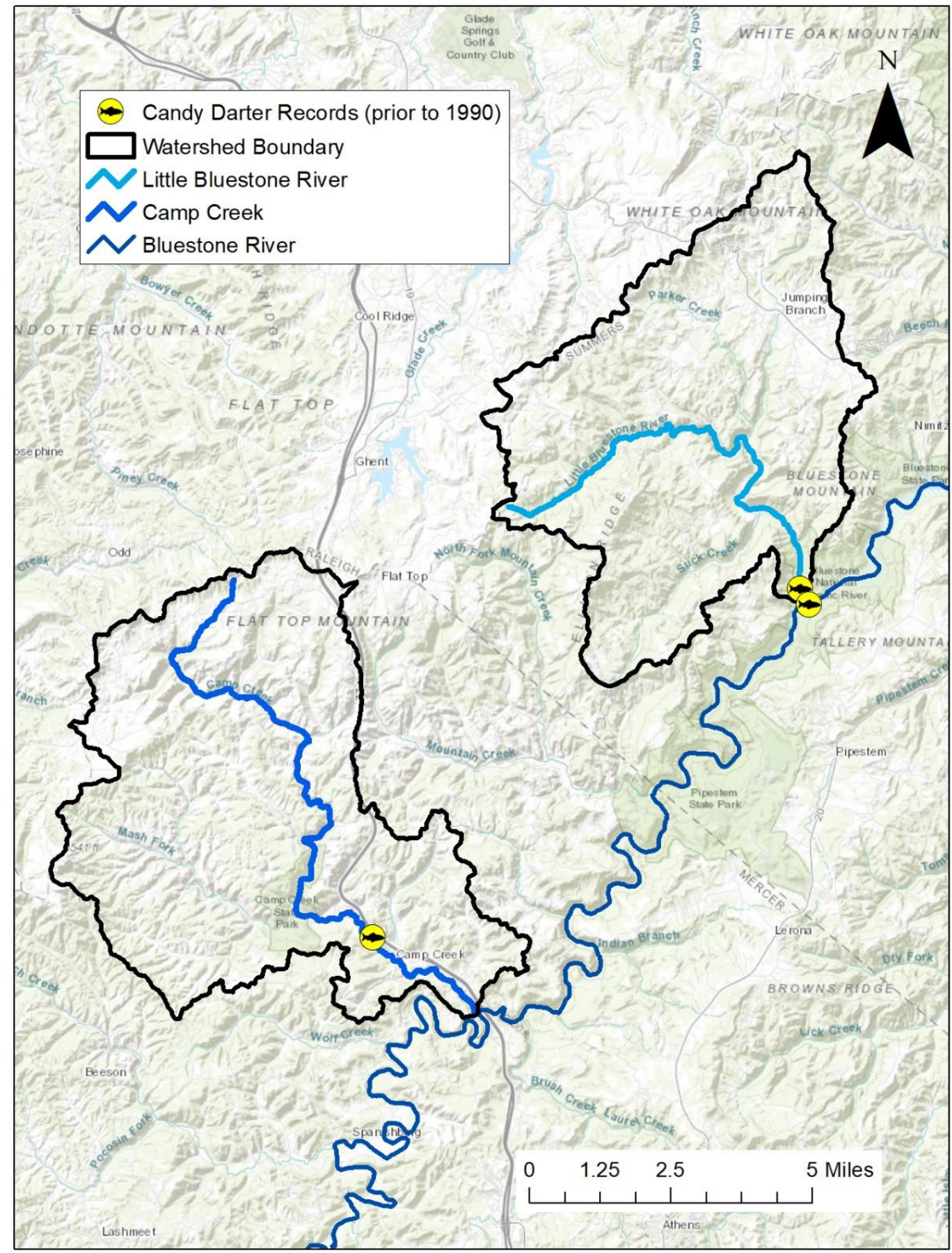

Figure 1. Records of E. osburni prior to 1990 in Camp Creek and the mouth of the Little Bluestone River. 


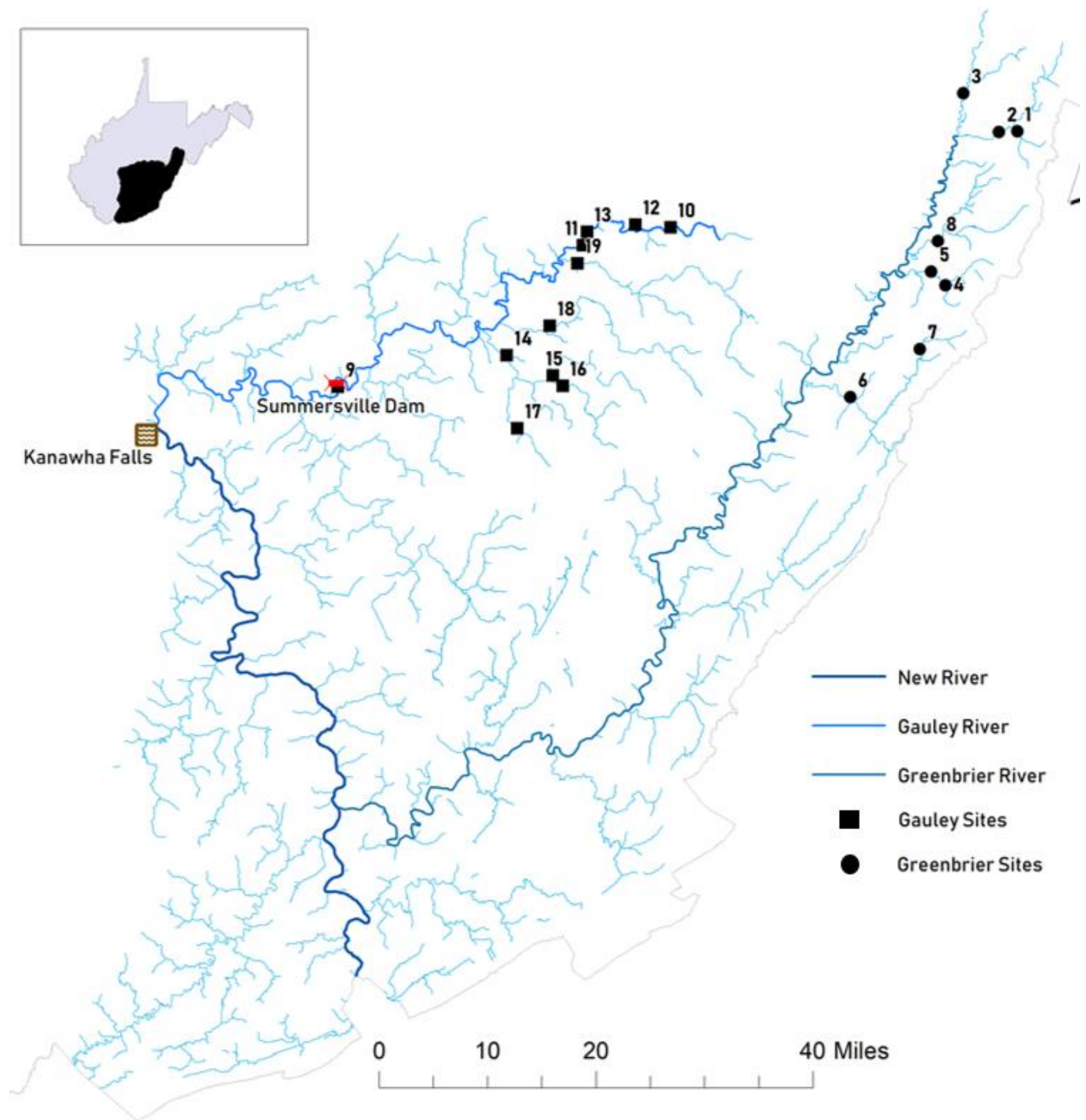

Figure 1. E. osburni collection locations. The numbers correspond to information contained in Table 2. Squares represents sites in the Gauley River drainage and circles represent sites in the Greenbrier River drainage. 


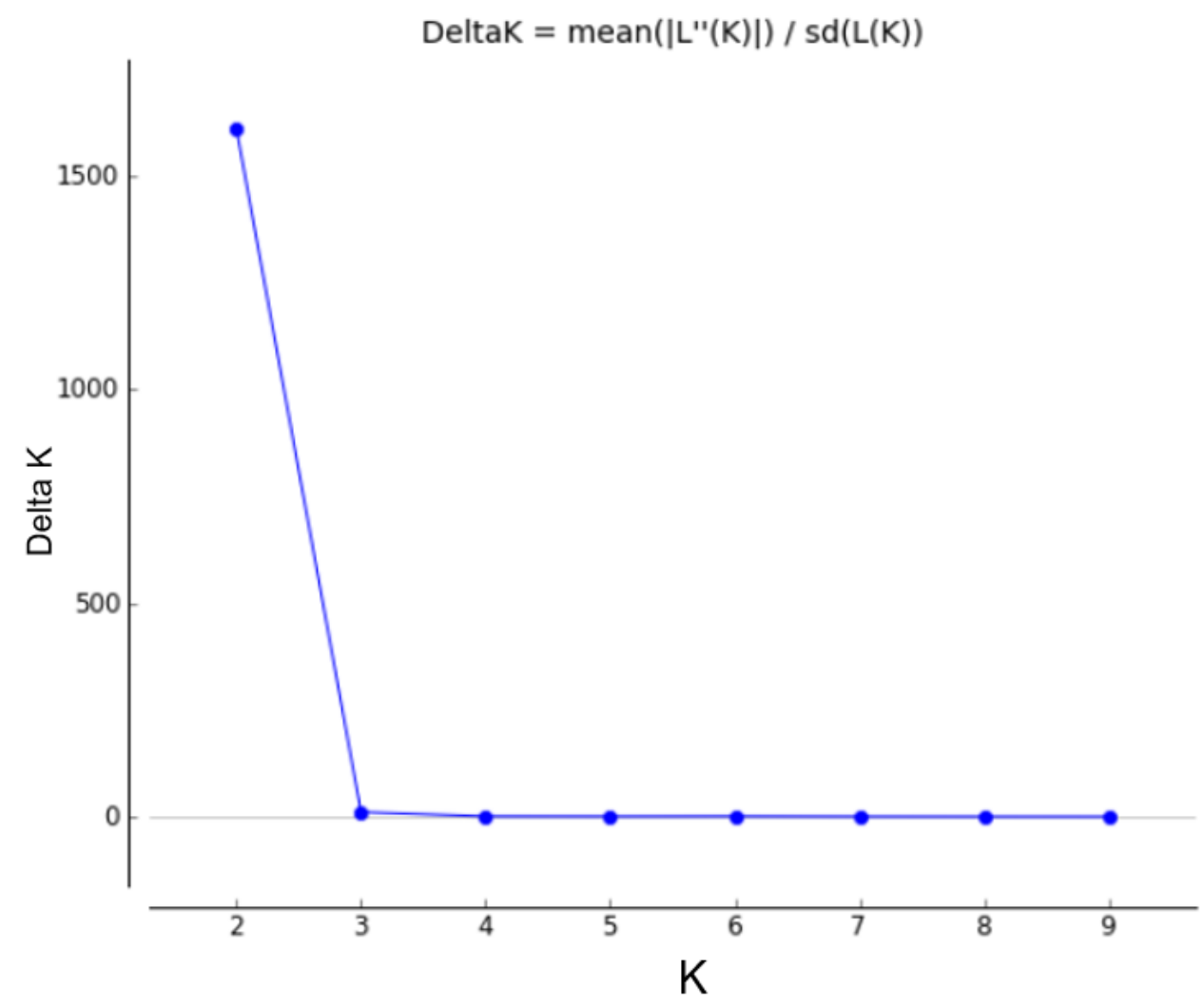

Figure 3. Results from application of the Evanno et al. (2005) method for determining the most likely number of genetic clusters (K) in STRUCTURE. DeltaK = change in log probabilities of each $\mathrm{K}$, mean $(\mid \mathrm{L}$ ' $(\mathrm{K}) \mid)$ = mean log likelihood among replicates for each value of $\mathrm{K}, \mathrm{sd}(\mathrm{L}(\mathrm{K}))=$ standard deviation of log likelihoods among replicates for the same K. 


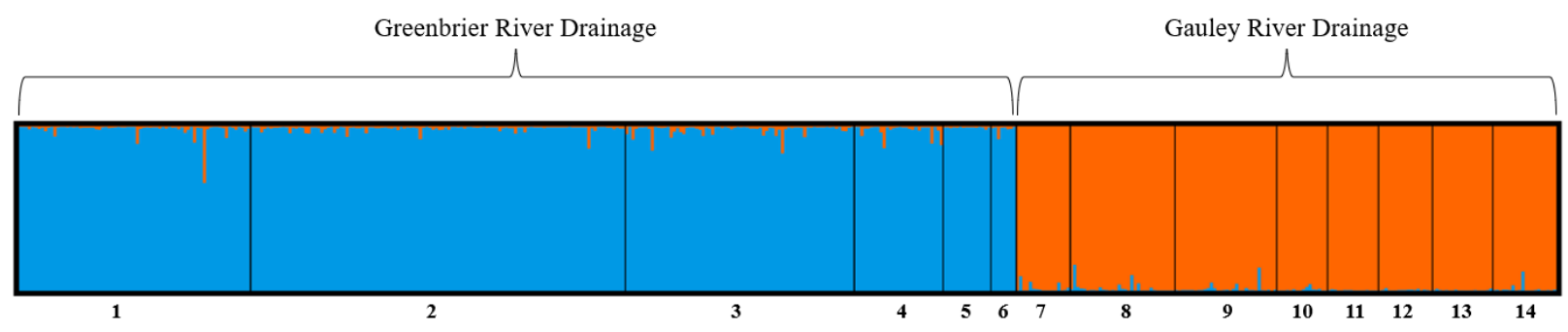

Figure 4. STRUCTURE diagram result from the most likely $(K=2)$ number of distinct genetic clusters. The numbers on the $\mathrm{x}$-axis correspond to subpopulations in Table 2 . The colors correspond to each of the two distinct genetic clusters. Each bar is an individual and the proportion of color in the bar corresponds to the probability of posterior assignment to that population. 


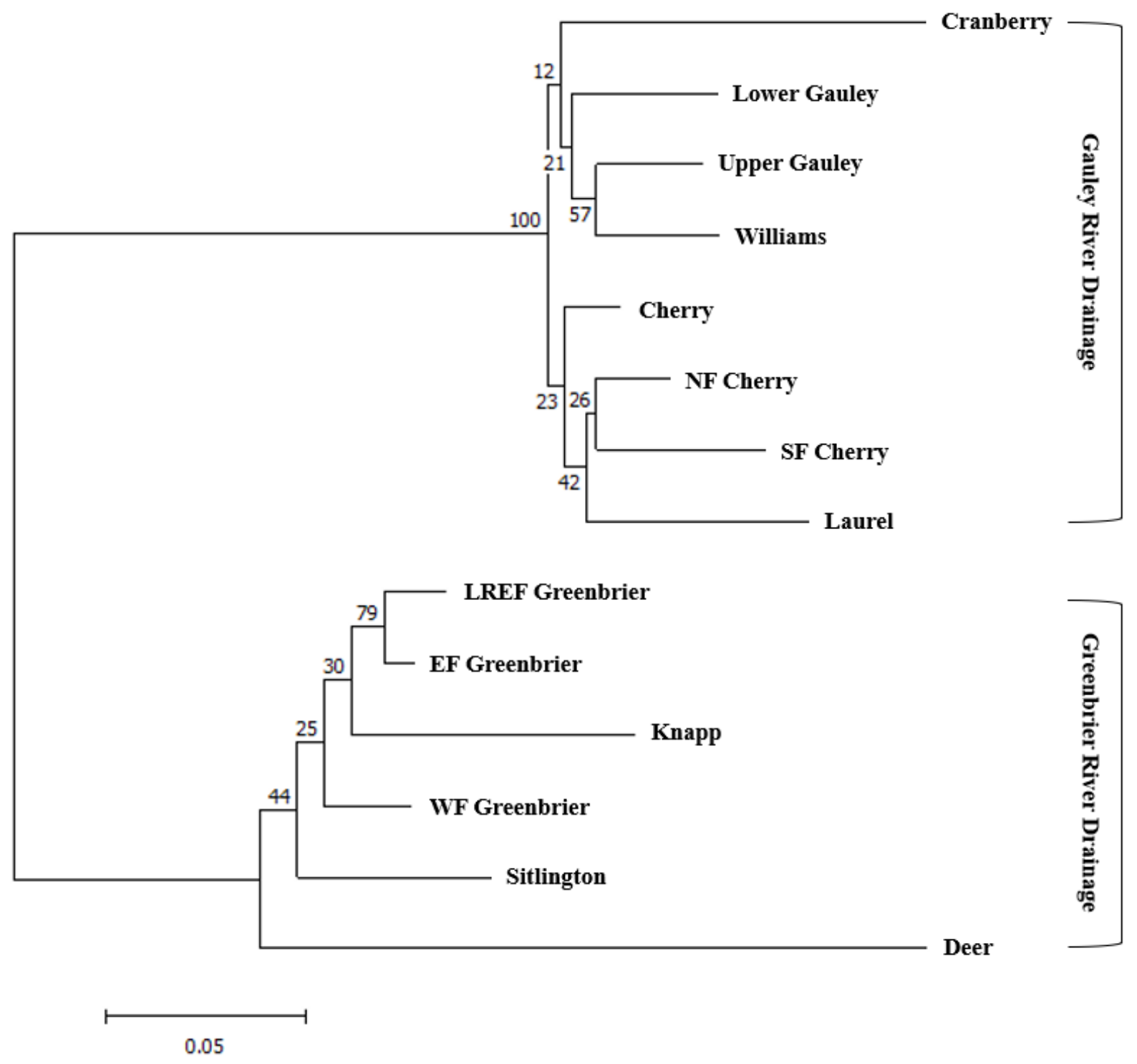

Figure 5. Neighbor-joining tree constructed using genetic distance ( $\mathrm{D}_{A}$; Nei et al. 1983). 


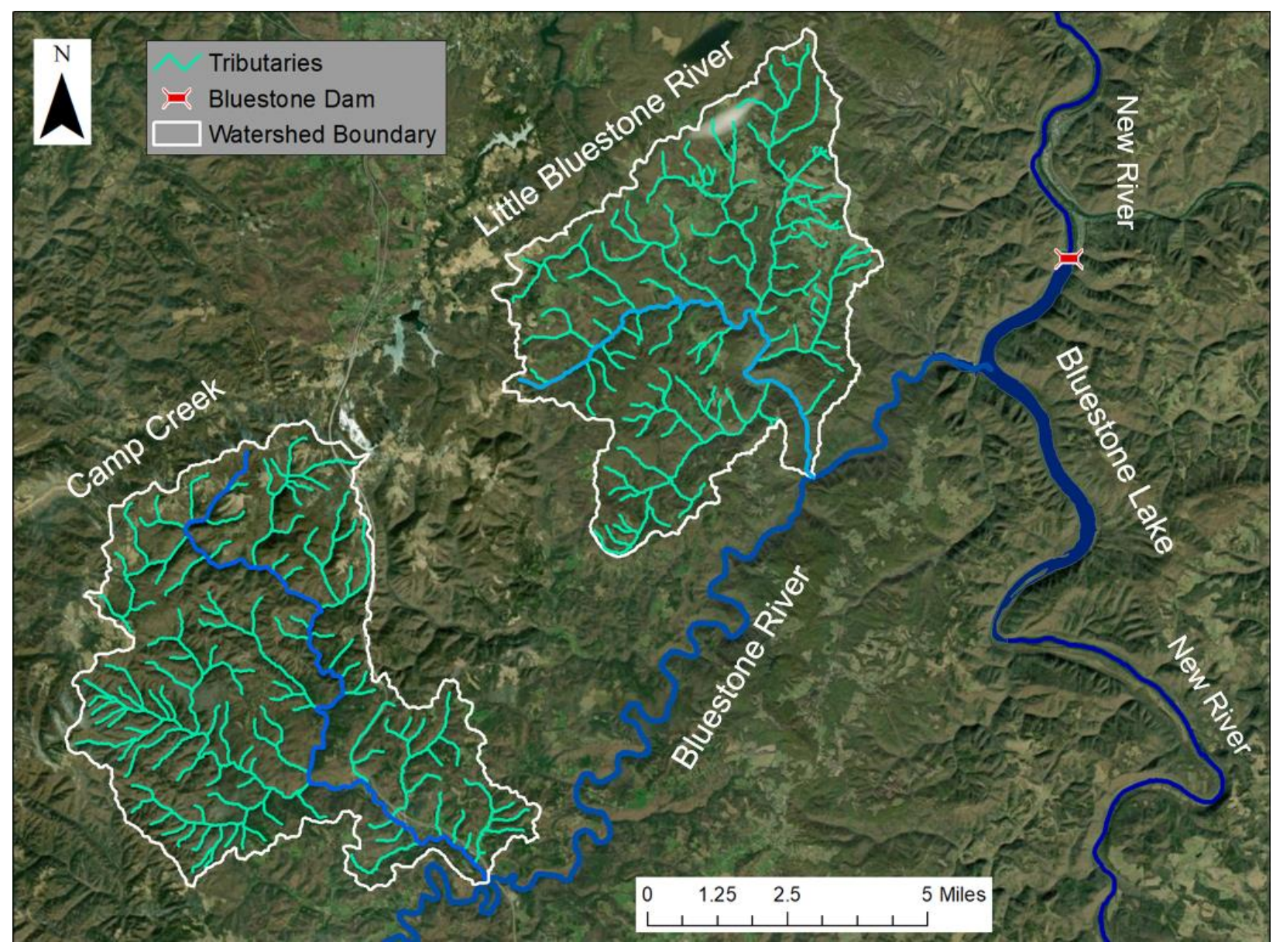

Figure 6. Satellite view of the CCW and the LBRW boundaries with their relation to the Bluestone and New Rivers that flow south to north. The mainstem rivers are light blue. Bluestone Lake is maintained by the Bluestone Dam and blocks E. variatum from moving into the Bluestone River drainage and the lower middle New River watershed. 


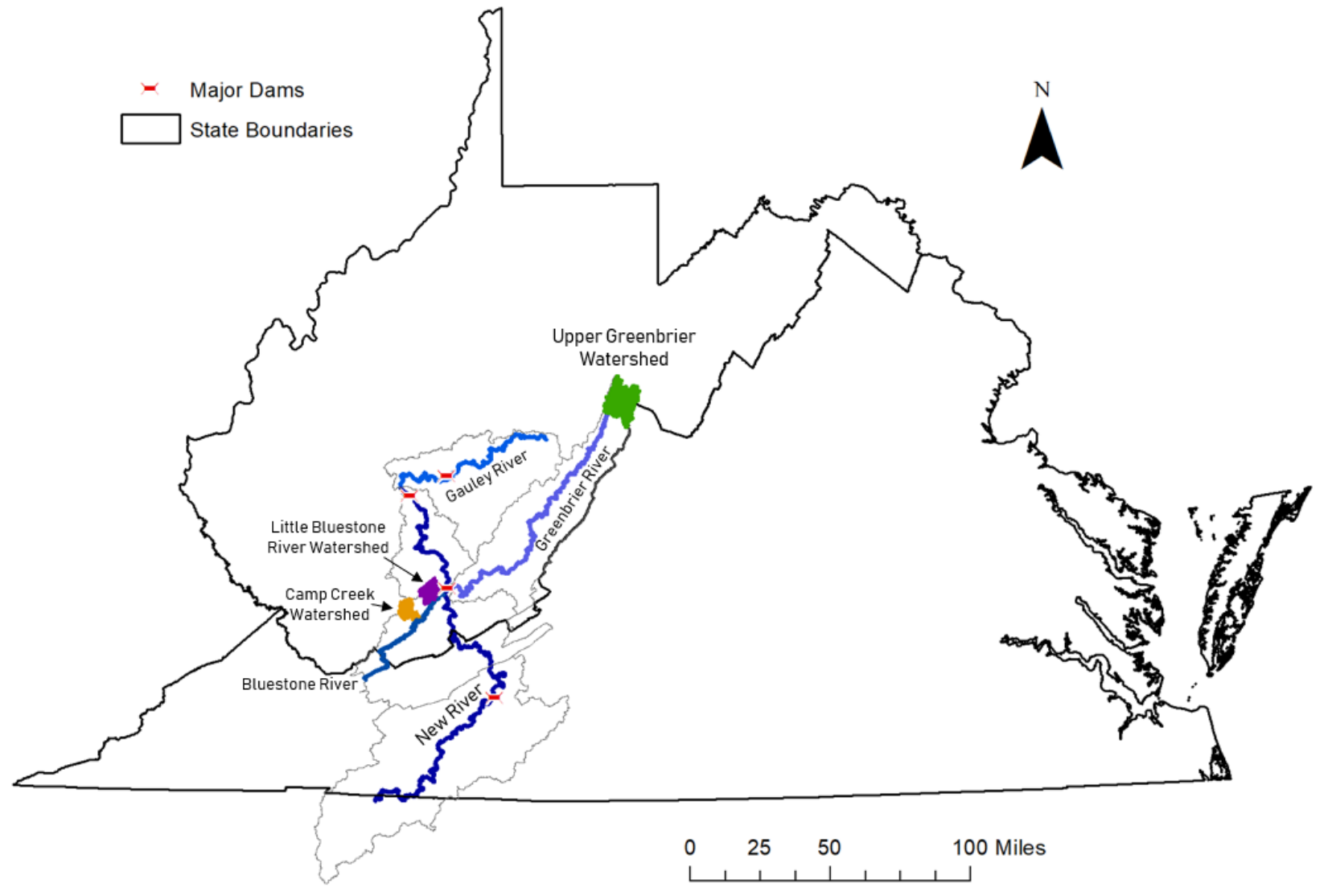

Figure 7. Map of the three watershed locations in West Virginia including major rivers in the New River Drainage. Light grey boundaries represent HUC-8 watershed boundaries where $E$. osburni is present. Major dams are barriers to the dispersal of E. variatum. 


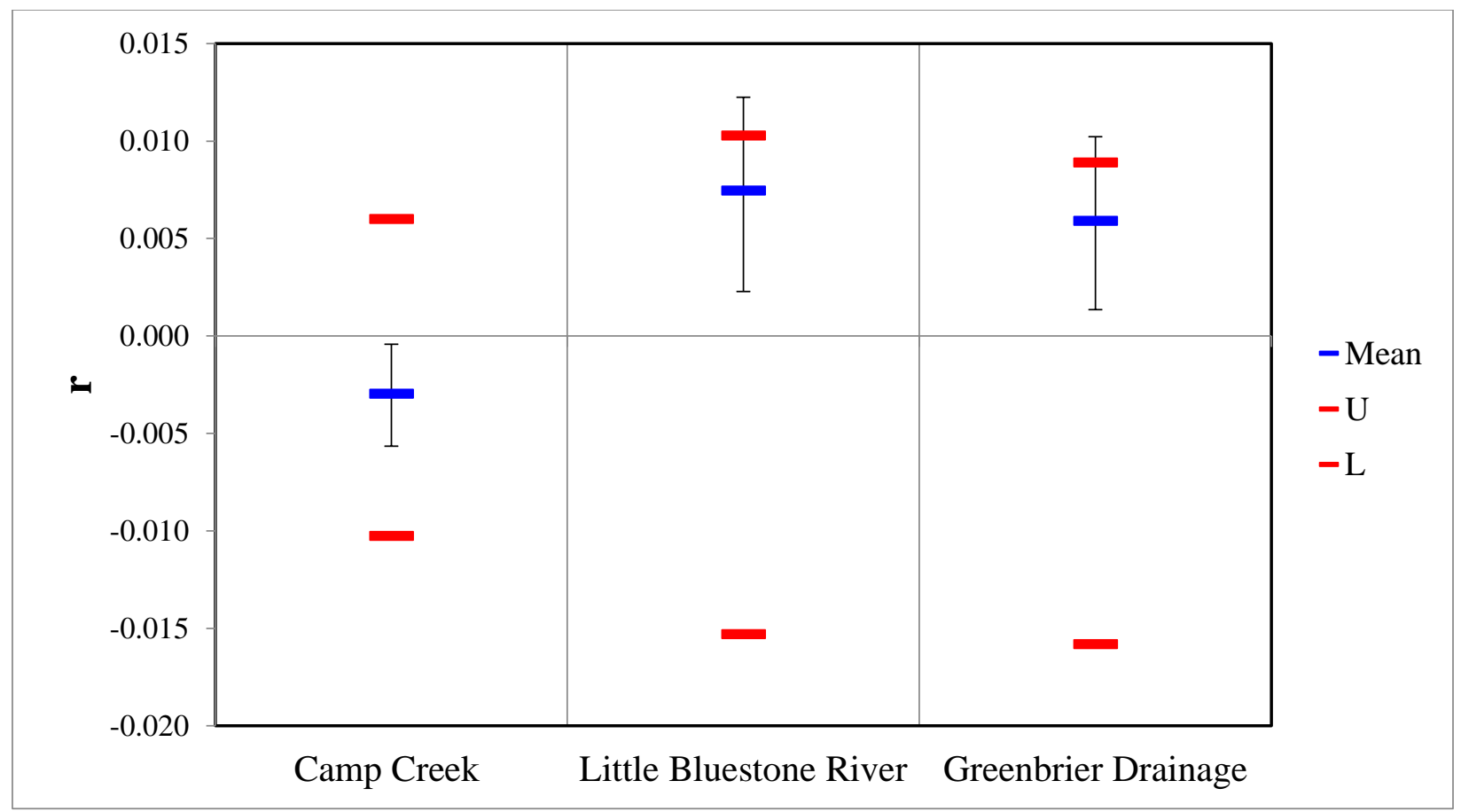

Figure 8. Mean within population pairwise relatedness (r) values for each population (Queller and Goodnight 1989). Upper (U) and lower (L) confidence limits bound the $95 \%$ confidence interval about the null hypothesis of 'No Difference' across the populations as determined by permutation. Upper and lower error bars bound the $95 \%$ confidence interval about the mean values as determined by bootstrap resampling. 


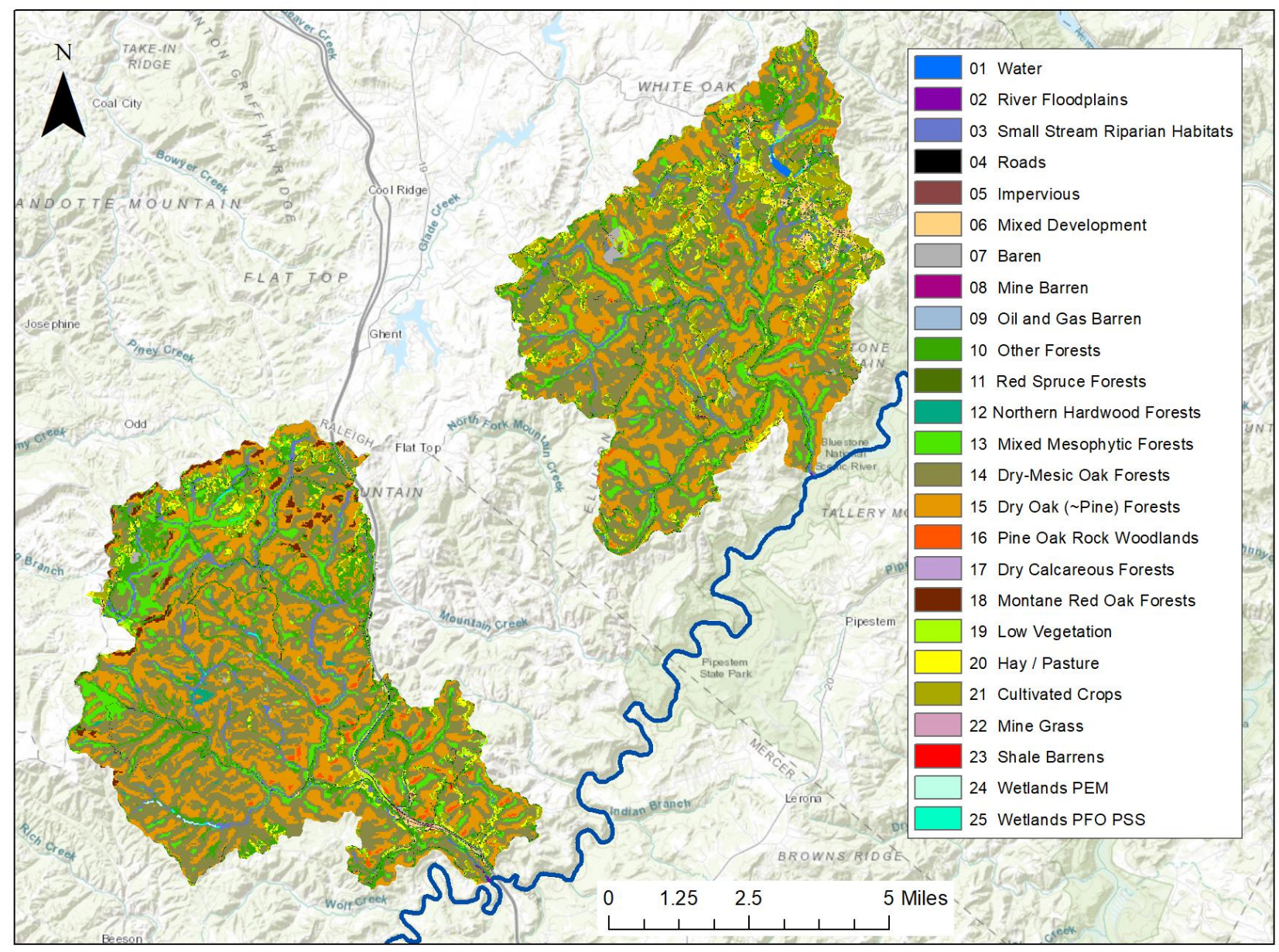

Figure 9. Land cover in the CCW and the LBRW from the NRAC statewide spectral classification for West Virginia using geographic object-based image analysis (GEOBIA), random forest (RF) machine learning, and National Agriculture Imagery Program (NAIP) orthophotography for mapping general land cover across the entire state. 

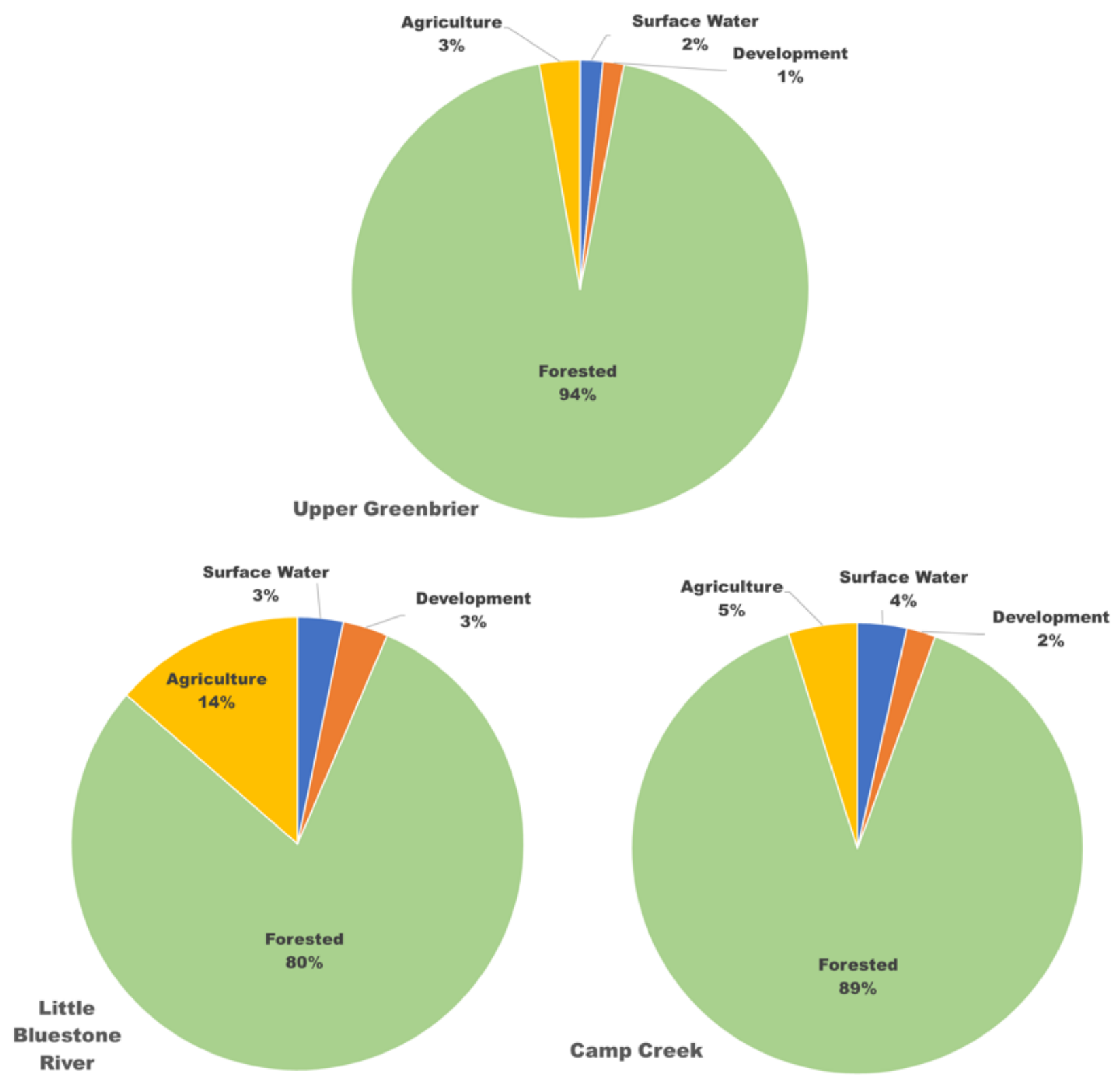

Figure 10. Land cover summary for each watershed using pie charts with the percentage of each generalized land cover category from Table 11. 


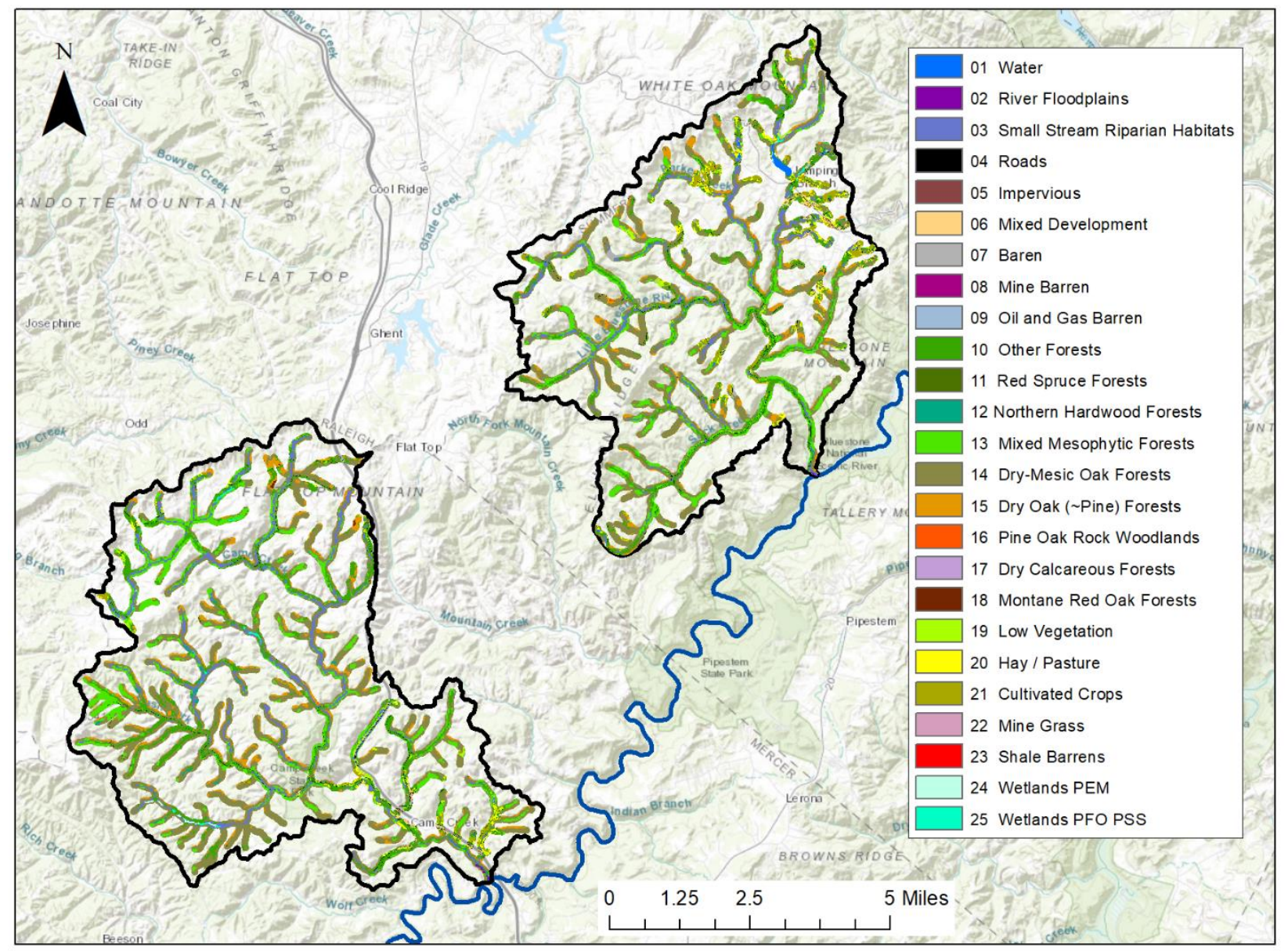

Figure 11. Land cover within $100 \mathrm{~m}$ of a stream to represent riparian zone land use. 


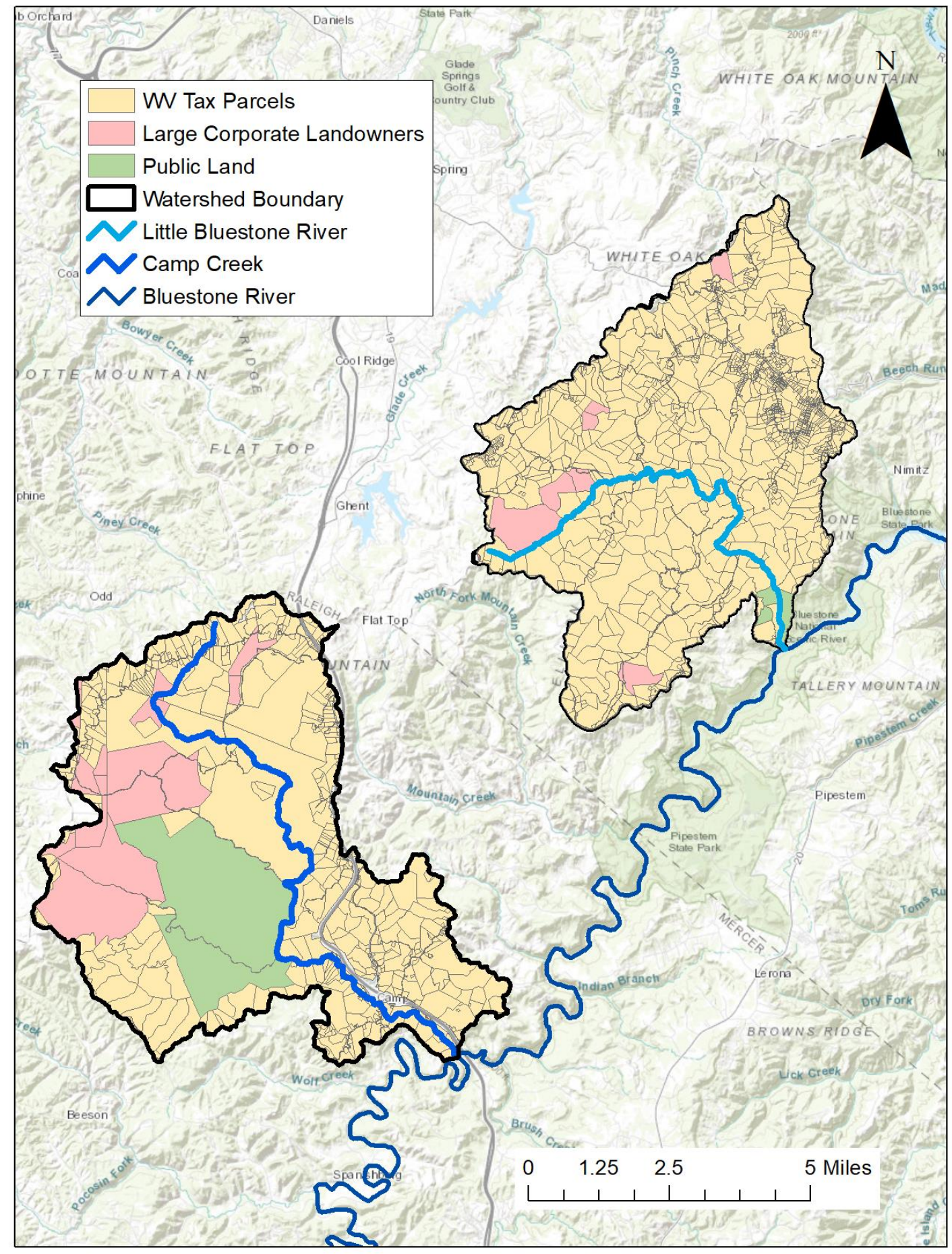

Figure 12. West Virginia 2018 surface tax parcel data representing different landowner types (public, private, and large corporate landowners). 


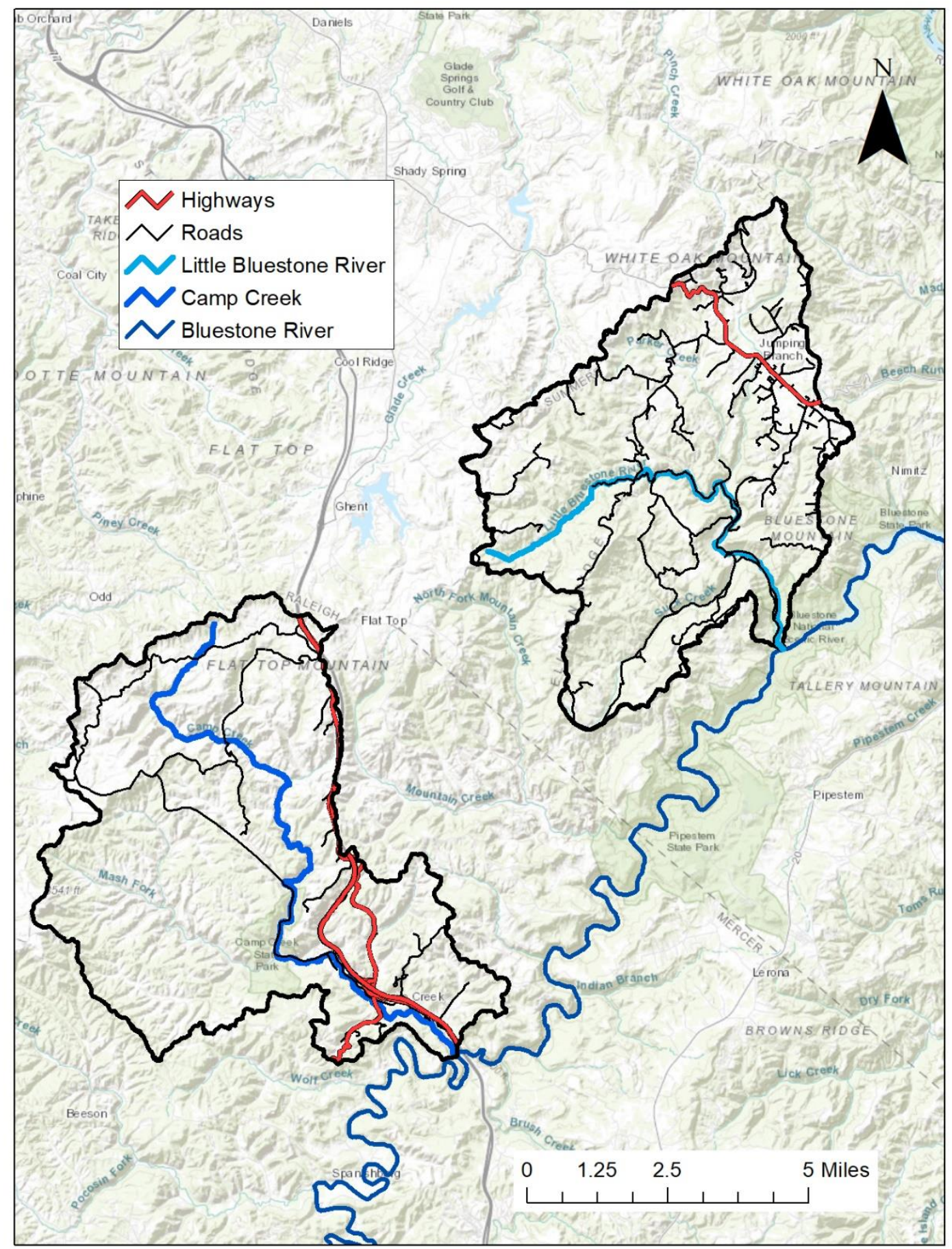

Figure 13. Roads and Highways within the CCW and the LBRW based on roads mapped by Esri's StreetMaps North America dataset (Esri 2012a). This includes small rural paved and unpaved roads, local roads, county and state highways, and federal highways. 


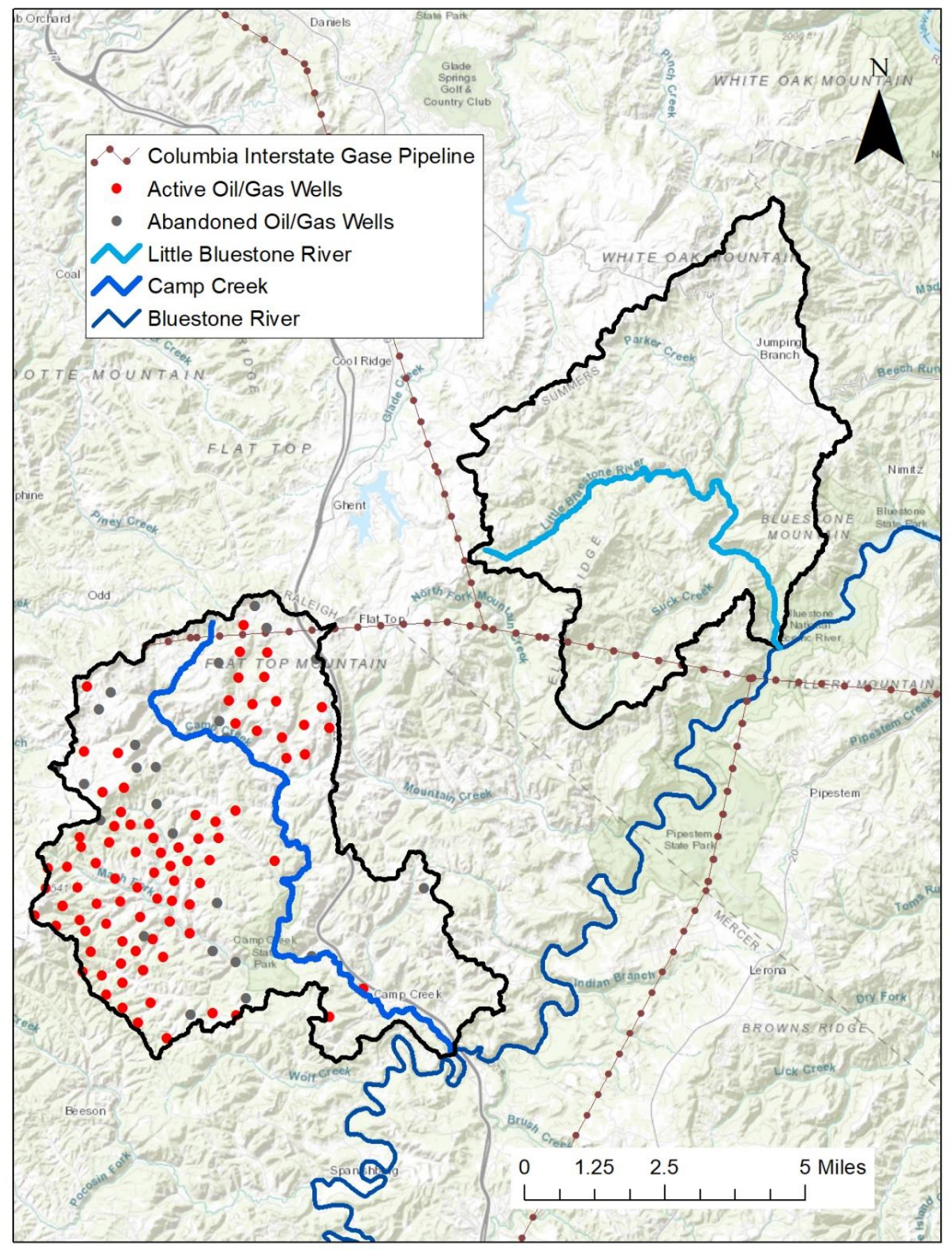

Figure 14. Resource extraction and transportation activities in the CCW and the LBRW. Abandoned oil and gas wells locations were found using the West Virginia Department of Environmental Protection database (WVDEP 2018). 